\title{
Agroecological practices in oil palm plantations: examples from the field
}

\author{
Cécile Bessou $^{1, *}$, Aude Verwilghen ${ }^{1,2}$, Laurence Beaudoin-Ollivier ${ }^{3}$, Raphaël Marichal ${ }^{1,4}$, \\ Jean Ollivier ${ }^{1}$, Victor Baron ${ }^{1,4}$, Xavier Bonneau ${ }^{1}$, Marc-Philippe Carron ${ }^{1}$, Didier Snoeck ${ }^{1}$, \\ Mohd Naim ${ }^{4}$, Anak Agung Ketuk Aryawan ${ }^{4}$, Francis Raoul ${ }^{2}$, Patrick Giraudoux ${ }^{2,5}$, \\ Erwanda Surya ${ }^{6}$, Edison Sihombing ${ }^{6}$ and Jean-Pierre Caliman ${ }^{4}$ \\ ${ }^{1}$ CIRAD, UPR systèmes de pérennes, 34398 Montpellier, France \\ 2 Department chrono-environment, UMR UFC/CNRS 6249 aff. INRA, University of Bourgogne Franche-Comté, 25030 Besançon, France \\ 3 CIRAD, UPR bioagresseurs, 34398 Montpellier, France \\ 4 SMART Research Institute, P.T. SMART Tbk., 28112, Pekanbaru, Indonesia \\ 5 Institut universitaire de France, Paris, France \\ ${ }^{6}$ P.T. Socfindo, P.O. Box 1254, 20001, Medan, Indonesia
}

Received 6 March 2017 - Accepted 24 April 2017

\begin{abstract}
Palm oil is nowadays the first vegetable oil consumed worldwide. Given the world population growth and the increasing demand in fat for food and fuel, the increase in oil palm production is expected to continue. It is thus important to find ways of reducing the ecological impact of oil palm plantations at both the agroecosystem and the mill supply area levels, by improving agricultural practices and land uses. This is where agroecology can play a very critical role. The present article gathers short stories on agroecological practices currently taking place in oil palm plantations in South-East Asia. Such stories notably highlight the importance of the various palm co-products and how appropriate recycling strategies can allow for reducing external inputs to both the field and the mill. Besides limiting environmental impacts thanks to such savings, several coproducts used as organic amendments can even help to maintain or enhance soil quality. Other stories explored agroecological practices developed for biological controls. Although integrated pest management has been applied in palm plantations for a long time, the underlying mechanisms are still not fully deciphered and practices still need to be improved. More knowledge is needed in order to better account for the holistic role of biodiversity and arbitrate trade-offs between practices and ecosystem services, at both plantation and landscape levels.
\end{abstract}

Keywords: palm oil / agroecology / biological control / recycling / composting / soil quality

Résumé - Pratiques agroécologiques en plantations de palmier à huile : exemples de terrain. L'huile de palme est aujourd'hui la première huile végétale consommée au monde. Étant donné la croissance démographique mondiale et la demande accrue en corps gras pour l'alimentation et les biocarburants, l'augmentation de la production d'huile de palme devrait perdurer. Il est ainsi primordial de trouver des moyens de production permettant de réduire l'impact écologique des plantations de palmier à huile, à la fois à l'échelle de l'agroécosystème et celle du bassin d'approvisionnement de l'huilerie, en améliorant les pratiques et la gestion des usages des sols. Les principes de l'agroécologie peuvent aider à développer des solutions à ces diverses échelles. Cet article rassemble diverses histoires courtes illustrant des pratiques agroécologiques mises en place dans des plantations de palmier à huile en Asie du Sud-Est. Ces illustrations mettent en évidence l'importance des nombreux co-produits issus du palmier et leur rôle clé dans les stratégies de recyclage pour réduire le recours aux intrants externes pour la plantation comme pour l'huilerie. Au-delà de la réduction des impacts environnementaux du fait de ces économies d'intrants, certains co-produits restitués en plantation peuvent également permettre de maintenir, voire d'améliorer, la qualité des sols. D'autres histoires courtes parcourent quelques autres pratiques agroécologiques dans le domaine de la lutte intégrée. Bien que de nombreuses pratiques de contrôle biologique soient mises en

\footnotetext{
* Correspondence: cecile. bessou@cirad.fr
} 
œuvre dans des plantations de palmier à huile depuis de nombreuses années, les mécanismes sous-jacents ont été encore peu explorés et les pratiques peuvent être améliorées. De nouvelles connaissances sont nécessaires pour mieux caractériser et prendre en compte de manière holistique les enjeux et le rôle de la biodiversité et pouvoir arbitrer les compromis entre pratiques et services écosystémiques, aux échelles de la plantation et du paysage.

Mots clés : huile de palme / agroécologie / contrôle biologique / recyclage / compost / qualité du sol

\section{Introduction}

Palm oil is the first vegetable oil consumed worldwide. Together palm oil and palm kernel oil represent more than one third of the vegetable oil market for only $6 \%{ }^{1,2}$ of the oil crops' total production area (Rival and Levang, 2013). As generally recognised, reasons for this pole position are the combined high productivity per hectare compared to other oilseed crops, the lower production costs and the great versatility in both oils' usages that are used in a very diverse number of agro-food products as well as in oleo-chemicals (Cock et al., 2016; Pirker et al., 2016; Rival and Levang, 2013). Hence, for the last 20 years, oil palm plantation area has drastically increased. The total productive area reached 18.7 Mha in 2014 compared to 7.5 Mha in 1994 according to the $\mathrm{FAO}^{1}$. This expansion was particularly remarkable in Indonesia and Malaysia, where productive areas increased over the same time period by a factor of 2 and 7, respectively ${ }^{1}$. Given the world population growth and the increasing demand in fat for food and fuel, the increase in oil palm production is expected to continue, albeit at a slower pace than in the last decade (OECD and FAO, 2013), and to extend to other developing or emerging countries in Africa and Latin America, where governments are promoting palm oil development to contribute to poverty alleviation and energy security (Pirker et al., 2016).

Most of oil palms are currently grown between $15^{\circ}$ latitude North and South of the equator below $500 \mathrm{~m}$ above the sea level without irrigation (Cock et al., 2016). This zone, where optimal conditions for palm oil production are met, also hosts the most intact tropical forests and the largest tropical peatland areas. Tropical forests and peatlands are valuable and rare ecosystems that represent critical reservoirs for both biodiversity and carbon. Conversion of those ecosystems into oil palm plantations has led to severe biodiversity losses (Fitzherbert et al., 2008; Foster et al., 2011; Koh and Wilcove, 2008; Savilaakso et al., 2014) and greenhouse gas emissions (Achten and Verchot, 2011; Bessou et al., 2014; Germer and Sauerborn, 2008; Reijnders and Huijbregts, 2008; Zulkifli et al., 2009). Further ecosystem services, such as erosion prevention, soil fertility or mitigation of extreme events, may be negatively impacted following the conversion of natural forests to oil palm plantations as an upper bound for possible changes in ecosystem functions (Dislich et al., 2016). Conversion of natural forests and peatlands to oil palm plantations or any other agricultural activity should be avoided as often as possible from an ecological point of view. This article is not discussing this issue further. Some authors have already

\footnotetext{
${ }^{1}$ http://www.fao.org/faostat, data on harvested areas for 2014, consulted on 28.1.2017.

${ }^{2}$ Soybean and rapeseed total areas are, respectively, 6 and 2 times greater than oil palm area based on FAO data on harvested total areas.
}

assessed the potential area for oil palm expansion without deforestation and peat conversion (e.g. Afriyanti et al., 2016). Definitely, the key issue is deforestation, and appropriate strategic land use planning at macro level is mostly needed. In addition, it is also important to find ways of reducing the ecological impact of existing and future oil palm plantations, by improving agricultural practices and land uses at the microlevel of the plantation and mill supply area. This is where agroecology can play a very critical role.

Agroecology is a paradigm shift in agronomy. Its conceptual framework was developed recently, when the limits of the green revolution were reached (Altieri, 1999; Conway, 1996; Griffon, 2007; Wezel et al., 2009). However, it can be perceived as a regain of more traditional views of agricultural activities embodied in their environment, i.e. acting in the present but thinking of the future. Agroecology is about understanding and enhancing the mechanisms that can ensure agroecosystem productions and resilience on the long-term. One cycle of oil palm plantations lasts for 25 years at least. The crop could last much longer but the harvest becomes too complex and expensive as soon as the palms are too high, hence palms are felled and another crop cycle initiated. The crop stand goes through two main phases: the immature one that lasts around 3 years during which bunches are not harvested; and the mature phase during which bunches are harvested all year long. These long and partitioned cycles require a specific management that usually combines longterm management strategies and short- or medium-term adjustments. Moreover, it also implies complex and evolving interactions with the ecosystem that affect the potential performance of the crop and the efficiency of the management. Indeed, management impact on the production may be delayed due to the long-term development of the agroecosystem and may be more or less directly efficient or traceable due to internal buffer effects within the plant or the whole agroecosystem. Hence, long-term management is paramount for perennial cropping systems. In the search for long-term efficiency as well as in reaction to observers' critics, various agroecological practices have been developed in oil palm plantations. Some have become quite standard, such as the legume cover crop during the immature stage (Corley and Tinker, 2016) or are being promoted through best practice recommendations (e.g. Donough et al., 2009) and incorporated as criteria in several certification schemes (e.g. $\left.\mathrm{RSPO}^{3}, \mathrm{ISPO}^{4}\right)$. However, more data and scientific knowledge are still needed in order to quantify more accurately their

\footnotetext{
${ }^{3}$ Roundtable on Sustainable Palm Oil guidelines: http://www.rspo. org/key-documents/certification/rspo-principles-and-criteria, consulted on 28.1.2017.

${ }^{4}$ Indonesian Sustainable Palm Oil guidelines: http://www.ispo-org.or. id/index.php?lang=en, consulted on 28.1.2017.
} 
impacts on the agroecosystems and to develop further agroecological practices.

This article does not aim at reviewing either all agronomical practices or all potential affected or enhanced ecosystem services across the diverse oil palm cropping systems. Instead, it gathers several showcases of agroecological practices that are taking place in palm plantations. It proposes sound investigations of what is working and what should be improved in order to allow palm agroecosystems for being productive and resilient based on the understanding and enhancement of agroecological mechanisms. Sections 24 illustrate the opportunities and challenges related to the recycling of palm oil co-products within the agroecosystem. Then, Sections 5-7, highlight the role and importance of maintaining functional biodiversity within the oil palm landscape (Foster et al., 2011) through integrated pest management strategies.

\section{Recycling, i.e. harnessing the most of thermodynamics' principles}

Any production system aims at producing an added value to the inputs that enter the processes. Thermodynamics' principles somehow signify that this added value can be enhanced by recycling energy and materials as much as possible but it always comes at a cost. In agricultural systems notably, this cost is two-fold, economic and environmental. Reducing costs is achieved by reducing the input-output (leakage) flows and enhancing recycling internal flows. This is actually quite critical in oil palm agroecosystems because of the large internal fluxes over the whole perennial cycle (Pardon et al., 2016) and the necessary close spatial connection to the mill (within a radius of $50 \mathrm{~km}$ ), and its in and out fluxes, due to the perishable fruits that must be processed within 24 hours after harvest (Lake et al., 2016).

Palm plantations require fertilisers, notably $\mathrm{N}, \mathrm{P}, \mathrm{K}, \mathrm{Mg}$, $\mathrm{Cl}, \mathrm{B}$, albeit fertiliser types and rates highly vary with the context. For instance, N doses ranges from 48 to $90 \mathrm{~kg} \mathrm{~N}$. $\mathrm{ha}^{-1} \cdot \mathrm{yr}^{-1}$ for immature palms (Banabas, 2007; Choo et al., 2011; Henson, 2004) and from 56 to $206 \mathrm{~kg} \mathrm{~N} \mathrm{ha}^{-1} \cdot \mathrm{yr}^{-1}$ for mature palms (FAO, 2004; Foster, 2003; Hansen, 2007; Pardon et al., 2016; Wicke et al., 2008). In an established palm plantation, fertilisers can account for 46 to $85 \%$ of field costs (Caliman et al., 2001; Goh and Härdter, 2003; Goh and Po, 2005; Pardon et al., 2016; Silalertruksa et al., 2012). Moreover, part of these fertilisers may be lost to the environment leading to potential environmental impacts such as eutrophication or climate change. Fertiliser manufacturing, transport and emissions in the field are one of the main contributors to environmental impacts throughout the life cycle of palm oil and palm biodiesel. Fertilisers are key contributors to both eutrophication and acidification (Schmidt, 2010; Stichnothe and Schuchardt, 2011; Vijaya et al., 2009; Yusoff and Hansen, 2005), fossil resource depletion (Papong et al., 2010) and climate change (Bessou et al., 2014; Chase and Henson, 2010; Choo et al., 2011; Schmidt, 2010).

The great share of environmental burdens related to fertiliser is accentuated by the fact that the other stages of the life cycle of palm oil production are low-input stages. In the field, in industrial estate as in smallholders' plantations, most operations are done manually (harvesting, pesticide spreading, fertiliser application at young ages); the most fuel-intensive operation is the transport of fresh fruit bunches to the mill (Chase and Henson, 2010). At the mill, the whole operation system is almost energy independent due to routine recycling processes (Kurnia et al., 2016; Yusoff, 2006). Fibers and shells recovered from palm oil extraction and kernel cracking are burnt in the boiler providing heat and electricity to power oil milling processes. Methane emissions during the anaerobic treatment of palm oil mill effluents in open ponds are a very critical source of greenhouse gas emissions, even in some cases larger than those generated by fertilisers. However, the impact of this conventional effluent treatment can be significantly reduced if biogas is captured at the mill (Bessou et al., 2014; Chavalparit et al., 2006; Choo et al., 2011; Harsono et al., 2014) or, to a lesser extent, if raw or partially treated effluents are injected in a composting process (Singh et al., 2010; Stichnothe and Schuchardt, 2010). This captured biogas can be flared and converted to electricity, in which case excess electricity may substitute fossil electricity from the grid.

Hence, palm oil co-products are numerous and provide various alternatives to optimise recycling processes, reduce external inputs, and further contribute to fossil input substitution (Fig. 1 by Paltseva et al., 2016). On the basis of their national assessment for Indonesia, the authors estimate that around $24 \%$ of total palm residues (i.e. 4.5 tonnes [t] DM/ ha. $\mathrm{yr}^{-1}$, which is close to the weight of the concomitantly yielded crude palm oil) could be used to produce and export bioenergy outside of the mill (Paltseva et al., 2016). The total solid biomass could allow for the production of advanced biofuels that could substitute $15 \%$ of the total road fuel consumption. The biogas captured from palm oil mill effluent could further substitute $3 \%$ of total annual diesel and gasoline demand (Paltseva et al., 2016). According to several authors, the methane capture from all palm mills in Indonesia and conversion to electricity would suffice to meet the GHG reduction target for agriculture (Taniwiryono and Herman, 2016). However, there is still a long way to go. Indeed, in 2016 , roughly 39 out of the 740 mills had implemented biogas capture in Indonesia (Taniwiryono and Herman, 2016). In Malaysia, 55 out of the 426 mills had implemented methane capture in 2011 and 16 other plants were under construction (Chin et al., 2013).

Besides, there is also an internal need within palm agroecosystems to substitute fossil inputs and reduce mineral fertiliser inputs. Although fronds and stipes already provide some organic material back to the system, further residues can be used as soil amendments. In particular, empty fruit bunches can be applied in the field in order not only to provide potassium but also to contribute to the improvement of soil fertility, notably on soils which are poor in organic matter (see Sect. 3) (Carron et al., 2015a,b; Salètes et al., 2004a). Empty fruit bunches can also be co-composted with palm oil mill effluent and ashes, which can increase the nutrient value and benefits from the amendment while also reducing transport costs as compost is less bulky and more concentrated in nutrients (Singh et al., 2010, 2011). Other types of co-compost can also be explored such as a mix of palm fronds with palm oil mill effluent sludge (Ahmad et al., 2011). Integrated 


\begin{tabular}{|c|c|c|c|c|c|}
\hline & Residue type & $\begin{array}{l}\text { Productlon } \\
\left.\text { (dry } t \text { ha-1 }^{-1} r^{-1}\right)\end{array}$ & $\begin{array}{l}\text { Use as soll } \\
\text { amendment } \\
\text { (dry } t h^{-1} \mathrm{yr}^{-1} \text { ) }\end{array}$ & $\begin{array}{l}\text { Use for heat } \\
\text { and power } \\
\text { (dry } t \text { ha }^{-1} \mathrm{yr}^{-1} \text { ) }\end{array}$ & $\begin{array}{l}\text { Net avallabillity } \\
\text { (dry } t \mathrm{ha}^{-1} \mathrm{yr}^{-1} \text { ) }\end{array}$ \\
\hline \multirow{4}{*}{$\begin{array}{l}\text { Processing } \\
\text { residues }\end{array}$} & $\begin{array}{l}\text { Empty frult } \\
\text { bunches }\end{array}$ & 1.6 & 0 & 0 & 1.6 \\
\hline & $\begin{array}{l}\text { Palm kernel } \\
\text { shells }\end{array}$ & 1.1 & 0 & 0.6 & 0.5 \\
\hline & $\begin{array}{l}\text { Palm press } \\
\text { flber }\end{array}$ & 1.7 & 0 & 0.9 & 0.8 \\
\hline & $\begin{array}{l}\text { Palm oll } \\
\text { mIII effluent } \\
\text { (POME) }\end{array}$ & 0.7 & 0 & 0 & 0.7 \\
\hline \multirow{2}{*}{$\begin{array}{l}\text { Fleld } \\
\text { resldues }\end{array}$} & Fronds & $\begin{array}{c}0.6 \text { (felling) } \\
10.4 \text { (pruning) }\end{array}$ & 11.0 & 0 & 0 \\
\hline & Trunks & 2.8 & 1.9 & 0 & 0.9 \\
\hline & TOTAL & 18.9 & 12.9 & 1.5 & $\begin{array}{l}\text { Final residue } \\
\text { avallabillty: } 4.5\end{array}$ \\
\hline
\end{tabular}

Fig. 1. Annual average per-hectare production, uses, and sustainable availability of oil palm residues in Indonesia according to Paltseva et al. (2016). Further down the process chain, potentially useful waste or co-products are palm oil mill sludge, palm oil clinker and ashes (Liew et al., 2006).

combination of methane capture and compost production may also be a suitable option (Stichnothe and Schuchardt, 2010; Yoshizaki et al., 2013). The comparison of these different options in order to harness the best from all potential recycled materials need to account for both the benefits and risks for the palm agroecosystem and the potential net input-output gain at the whole supply chain level. Life cycle assessment (LCA) allows for such a holistic analysis of various environmental impacts over the whole supply chain, taking into account potential substitutions and avoided impacts (Bessou and Pardon, 2017; Chiew and Shimada, 2013; Stichnothe and Schuchardt, 2010, 2011; Wiloso et al., 2015).

However, LCA of palm oil products still need to be improved in order to better account for practices and impacts along the whole chain (Stichnothe and Bessou, 2017). On the one hand, data are still missing on the upstream emissions during the various co-products' treatments such as the composting processes. On the other hand, knowledge and data are also missing to better model the downstream processes and emissions when recycling co-products. In particular, the influence of practices on temporary storage of soil carbon, improvement of soil quality and protection from soil erosion are not currently part of the life cycle impact assessment (Stichnothe and Schuchardt, 2011). In order to design the best environmental friendly scenarios for residues and global plantation managements, a proper modelling of impact on the soil is crucial.

\section{Feeding soil quality with empty fruit bunches}

Empty fruit bunches (EFB) are among the primary coproducts of palm oil production in terms of quantity: for each tonne of crude palm oil, about $1 \mathrm{t}$ of EFB is produced (Caliman et al., 2001). In the early days of the oil palm cultivation development, EFB were disposed or incinerated. However, given the increase in fertiliser costs due to fossil resource depletion and the raise in awareness concerning air pollution $^{5}$ and greenhouse gas emissions due to EFB burning (Abu Bakar et al., 2011), the field application of EFB as an organic amendment was progressively developed at the end of the twentieth century (Caliman et al., 2001; Carron et al., 2015a). Such EFB application as mulch is expected to have a positive impact on soil quality, since organic matter is known to play a key role in soil quality (Lal, 2004; Reeves, 1997). Soil quality is defined as the complex resultant from various chemical, physical and biological properties that determines "the fitness of a specific kind of soil to function within its surroundings, support plant and animal productivity, maintain or enhance water and air quality, and support human health and habitation" (Karlen et al., 1997). How can EFB field application as mulch help to preserve or enhance soil quality in oil palm plantations?

EFB application can first contribute to improving chemical properties of the soil, in particular its nutrient content for the purpose of fruit production, i.e. the "support function". EFB application rates depend on the soil context and also on the management strategy. Recommended rates vary between 30 to $100 \mathrm{t} \cdot \mathrm{ha}^{-1} \cdot \mathrm{yr}^{-1}$, with a median rate at $40 \mathrm{t} \cdot \mathrm{ha}^{-1} \cdot \mathrm{yr}^{-1}$ (Etta et al., 2007; Jantaraniyom et al., 2001; Loong et al., 1987; Mohsen et al., 2014; Zin and Tarmizi, 1983). In terms of nutrient content, $1 \mathrm{t}$ of EFB is approximately equivalent to $6-7 \mathrm{~kg}$ of urea $1.7 \mathrm{~kg}$ of triple super phosphate or $2.8 \mathrm{~kg}$ of rock phosphate, $16.3 \mathrm{~kg}$ of $\mathrm{KCl}$ or $19.3 \mathrm{~kg}$ of muriate of potash, and 3-4.4 kg of kieserite (Caliman et al., 2001; Singh et al., 1999). Potassium is the most important nutrient provided by EFB, given the fast EFB decomposition (Fig. 2) and quick release rate (Zaharah and Lim, 2000). The release of nitrogen is much slower, likely due to some immobilisation given the high $\mathrm{C} / \mathrm{N}$ ratio of EFB (52-63). Therefore, within the limit of the available amount that approximates 3-5 t EFB produced per

\footnotetext{
${ }^{5}$ See for instance the Malaysian Environmental Air Quality Regulation in 1978.
} 


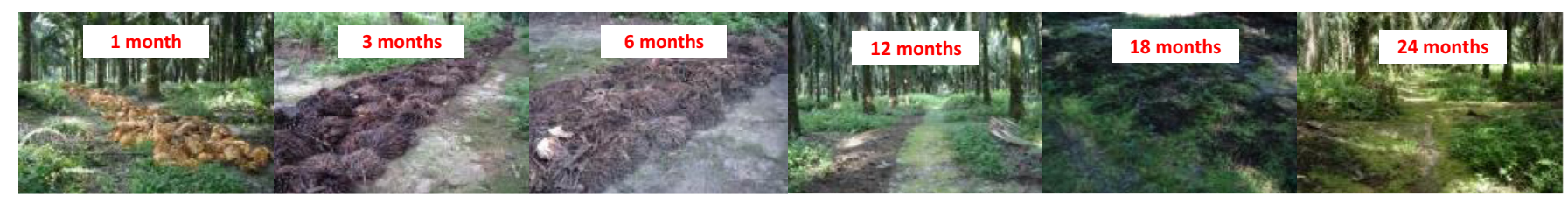

Fig. 2. EFB decomposition in the field: 1, 3, 6, 12, 18 and 24 months after application. EFB decomposition leads to an improvement of global soil quality, showing, among other improvements, higher soil macrofauna abundance and soil organic carbon content, Indonesia, Marc-Philippe Carron ${ }^{\circledR}$ Cirad.

hectare per year, EFB can be used as total substitutes for $\mathrm{K} / \mathrm{Mg}$ for some $10 \%$ of the plantation but still complemented with mineral nitrogen and phosphate. Besides the nutrient inputs, EFB can also further improve physico-chemical properties of the soil. Short-term and long-term studies (10 years application) showed an improvement of soil chemical quality through the following indicators: soil organic carbon, total nitrogen, CEC, and available phosphorus (Abu Bakar et al., 2011; Caliman et al., 2001; Comte et al., 2013). EFB application can also improve some physical properties of the soil related to both the addition of soil organic carbon and physical mechanisms such as the mulch effect. Those allow for better soil permeability (Caliman et al., 2001; Carron et al., 2015b), higher water retention at field capacity, better soil aggregate stability and hence lower erodibility (Moradi et al., 2015; Zaharah and Lim, 2000).

While the impact of EFB recycling on chemical and physical soil properties is well documented, attention has been only recently paid to the impacts on soil biological properties, i.e. soil biodiversity. Soil biota directly contributes to the regulation and long-term maintenance of several ecosystem functions and services including primary production, carbon sequestration and nitrogen turnover (Brussaard, 2012; Lavelle et al., 2006; Wagg et al., 2014). The influence of management practices on soil biodiversity hence needs to be investigated (Brussaard, 2012; Lavelle et al., 2006).

In Indonesia, at P.T. SMART research institute, building-up on previous research projects on the impact of EFB application on soil properties (Caliman et al., 2001; Salètes et al., 2004a, b), new measurement protocols were designed in order to assess the impacts on soil biodiversity (Carron et al., 2015a,b). Results showed that EFB application:

- allowed for a global improvement of soil quality, showing higher macrofauna and soil organic carbon content;

- impacts on soil characteristics varied in terms of affected species depending on the assessment delay after application (Carron et al., 2015a).

During the first 6-month period after EFB application, ants and coleopteran densities increased to reach 349 ind. $\mathrm{m}^{-2}$ and 95 ind. $\mathrm{m}^{-2}$; respectively, as well as bacterial feeder nematodes. On the contrary, the population of earthworms, millipedes and nematodes followed a different trend, showing a concomitant sharp decrease. In the following 12 months, the density of earthworms, millipedes and nematodes, as well as the population of bacterial feeder nematodes, progressively increased. Finally, during the final 6 months of EFB decomposition, the increase in densities of macrofauna (333 ind. $\mathrm{m}^{-2}$ ) and nematofauna (1068 ind $/ 100 \mathrm{~g}$ in the A0 and $788 \mathrm{ind} / 100 \mathrm{~g}$ in the A1 layer) was confirmed. Soil chemical and physical measurements also showed a reduction of soil bulk density with an induced increase in soil porosity, together with higher soil organic carbon, $\mathrm{N}$ and $\mathrm{Ca}$ contents (Carron et al., 2015a), thus highlighting the correlations between physico-chemical and biological properties of the soil.

The impact of EFB applications on soil bacterial diversity was also investigated through a metagenomic approach (Situmorang et al., 2014) using the terminal restriction fragments length polymorphisms (TRFLP) technique. EFB application increased soil bacterial diversity, especially of species involved in soil functions improving fertility. In addition, EFB decomposition was found to stimulate soil fauna feeding activity as observed using the bait-lamina strips method (Tao et al., 2016). This technique provides an indicator of the soil fauna feeding activity related to the presence of meso and microorganisms. Overall, these studies showed the positive impact of EFB application on soil quality, i.e. on soil physical, chemical and biological properties that confer to the soil its capacity to function. Enhanced soil biological properties encompassed increases in soil biodiversity, soil organism abundance and stimulated biological activity.

Recent observations have highlighted the general positive impact of EFB recycling on the biological fertility of soils, thus adding key knowledge and information to previous studies that were focusing on the physico-chemical properties of soils. The effect of EFB application on soil micro- and mesofauna has been poorly investigated and new approaches, like metagenomics or proteomics, are promising ways to assess soil microbial diversity and functions. So are techniques based on molecular biology approach aiming to assess soil microbial diversity and functions. Moreover, the next step will be to study more deeply the effects of EFB application on soil functions, going beyond the simple sum of the physical, chemical and biological parameters. This will allow for quantifying the effect of EFB application under the framework of an integrative view of soil ecosystem functions, in a multifunctionality and holistic approach. A holistic assessment is a key in order to design optimal co-product treatments and field management practices based on a sound and comprehensive understanding of all processes involved. Palm co-products are diversified and represent sizeable amounts of biomass but each of them, e.g. EFB or compost, may have different advantages and drawbacks and hence represent each a precious limited resource.

\section{Composting oil palm mill co-products}

Palm oil production is an industry generating large amounts of organic waste, which may lead to significant environmental concerns (Ahmad et al., 2011; Mohammad 
et al., 2012; Vakili et al., 2015). In Malaysia, in 2013, it was estimated that 63.18 million t of palm oil mill effluent (POME) and 7.26 million $t$ of empty fruit bunches (EFB) were generated (Bukhari et al., 2014). Such waste needs to be treated in order to reduce its pollutant loads. Digestion of raw POME, for instance, is mandatory in order to reduce its organic content before being discharged into the environment. Decomposition is not only important to avoid the harmful accumulation of organic pollutants, it may be also essential for recycling nutrients and organic matter, i.e. if wastes are considered as useful co-products. These recycled co-products may become useful to counteract the loss in quality of many soils due to an inadequate supply of organic matter or improper management, such as the loss of organic matter (Guillaume et al., 2015) or the occurrence of acidity due to ammoniumproducing fertilisers (Dubos et al., 2016). Research work undertaken on oil palm and other crops also showed that compost or organic matter application can also enhance root growth, improve soil structure and stability (Shindo et al., 2006), increase CEC and soil biological activity (Chakraborty et al., 2011), reduce iron and aluminum toxicity and significantly increase phosphorus availability in the soil (Budianta et al., 2010, Darmosarkoro and Sutarta, 2002).

These issues and opportunities have stressed the need to develop alternatives to conventional oil palm waste treatments, among which composting is a promising one. Composting can be defined as the biological transformation of organic matter by a succession of microorganisms under controlled environmental conditions (Baharuddin et al., 2009), usually in aerobic conditions with a thermophilic phase $\left(60-75^{\circ} \mathrm{C}\right)$ (Ceglie and Adbelrahman, 2014). It results in the degradation of organic matter and the emission of volatile compound $\left(\mathrm{CO}_{2}, \mathrm{CH}_{4}, \mathrm{~N}_{2} \mathrm{O}\right.$, $\mathrm{NH}_{3}, \mathrm{~N}_{2}, \mathrm{H}_{2} \mathrm{O}$ ) but also in the stabilisation of the remaining organic matter (Bernal et al., 1998; Francou et al., 2005) leading to the production of a humified, non-phytotoxic material (Kavitha et al., 2016) with high potentials for providing nutrients and increasing soil carbon. Through decomposition and stabilisation of organic matter, the composting process of palm oil co-products aims to reduce the organic co-products to essentials in terms of input qualities, i.e. nutrients and organic matter more directly "valuable" for the soil. Moreover, the use of a very significant part of POME volume within the process can help to reduce pollution and potential losses to the environment, notably greenhouse gas emissions (Stichnothe and Schuchardt, 2010). Composting oil palm mill co-products (EFB, decanter cake, fibre, POME, ashes) is an innovative and quite recent development in the palm oil industry in SouthEast Asia. In various countries, compost-manufacturing industries for palm oil residues are in constant development. In 2014, 70 composting plants, across 426 mills, were in operation in Malaysia, $80 \%$ of the plants are using the conventional open system and 20\% a closed system (Bukhari et al., 2014).

P.T. SMART Tbk., Indonesia, has carried out several composting trials since 1997 in order to identify the most interesting compositions and the best processing strategies. Results showed that it is possible after 14 weeks of composting to reduce the initial volume and weight of EFB by $80 \%$ and $55 \%$ respectively. Moreover, the high initial carbon to nitrogen $(\mathrm{C} / \mathrm{N})$ ratio in EFB can be decreased by addition of nitrogen-rich content products like urea or mature compost, which improves the activity of microorganisms for a faster

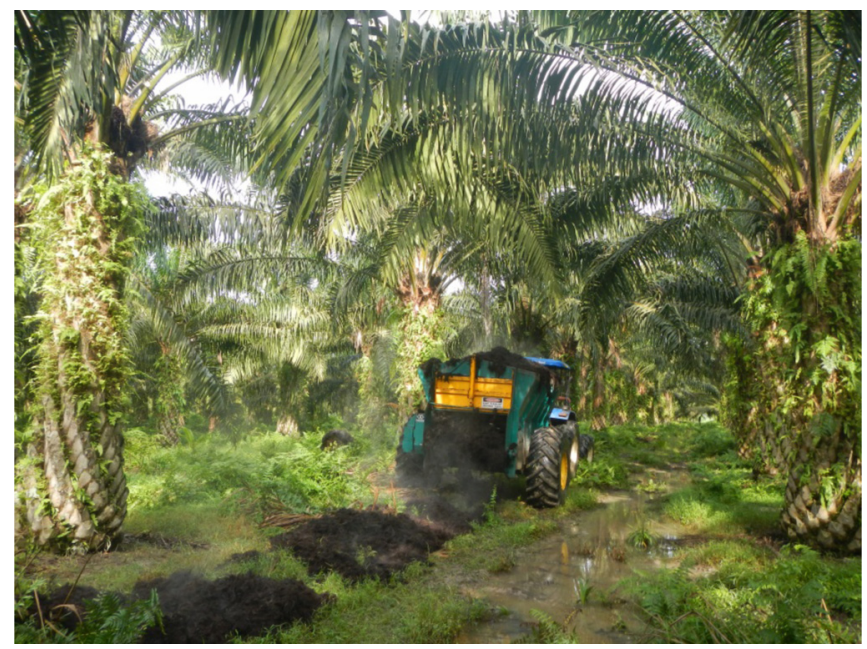

Fig. 3. Field application of compost from palm oil residues, 2013, Indonesia, Cécile Bessou (C)irad.

processing. The addition of mature compost at the initial stage of composting, followed by an application of urea 2 weeks later, showed the best beneficial effect (Salètes et al., 2004b). Schuchardt et al. (2002) obtained a $\mathrm{C} / \mathrm{N}$ ratio of 15 in 12 weeks, with a decrease in carbon of more than $60 \%$. Solid decanter waste (decanter cake slurry) addition can also significantly speed up the decomposing process of the POME and EFB mix (Yahya et al., 2010).

Another example is the innovative composting plant developed at Bangun Bandar, Indonesia, by P.T. Socfindo with aerated bunkers, which considerably reduces the compost processing duration and avoids losses of nutrients through leaching. Compost is made by using the pressed and shredded EFB, solid decanter, a compost starter from a previous batch and raw POME, which is sprayed onto the compost batch daily. Since the launching of the compost plant in 2012 , the quality of the compost has been continuously improved through adjustments in the maturation time and aeration rate. Composting enables the recovery of nutrients from raw POME. About 50\% of the POME from the mill is used in the composting plant. The nutrient content and the $\mathrm{C} /$ $\mathrm{N}$ ratio (below 20 in 2015) have been continuously improved through process adjustments and $\mathrm{K}$ content reached 2.5\% DM with a better recycling of the POME.

From a practical point a view, composting is interesting in order to reduce the weight and volume of EFB, making it easier and less expensive to apply in the field (Fig. 3). The nutrient content of compost is higher than EFB for $\mathrm{P}, \mathrm{K}$ and $\mathrm{Mg}$. Compost also enables a good recovery of nutrients from raw POME, without the need for previous treatment. The $\mathrm{K}$ release from EFB applied directly to the field is very quick; indeed half of the potassium is released in less than a month (Caliman et al., 2001). This could result in a very low efficiency of high doses of $\mathrm{K}$ brought to the field through the current method of EFB application (which varies from $40 \mathrm{t}$ up to $60 \mathrm{t} / \mathrm{ha}$ at once). With lower doses and a source of $\mathrm{K}$ partially incorporated in the microbial biota, it is likely that compost can improve $\mathrm{K}$ nutrition efficiency. However, the kinetics of $\mathrm{K}$ release after compost application would need to be measured and further investigated. 
At Bangun Bandar estate, in some mature plantation blocks, compost has been used for 4 years as a substitute to the standard mineral $\mathrm{P}, \mathrm{K}, \mathrm{Mg}$ and to part of the $\mathrm{N}$ fertilisers applied. The rate of $15 \mathrm{t} / \mathrm{ha}$ of compost applied can reduce the mineral fertilisers applied by up to $55 \%$. In the last 3 years, the average yield and the average leaf contents of major elements in these blocks were not significantly different from blocks with a standard exclusive mineral fertiliser treatment. Another study showed that a rate of 10 t.ha $^{-1}$ of compost (i.e. $70 \mathrm{~kg} / \mathrm{palm} /$ year) can be used as a substitute for mineral fertilisers regarding $\mathrm{N}$ and $\mathrm{P}$ nutrition (Tohiruddin and Foster, 2013). Under such conditions, compost would increase FFB yield by $2 \mathrm{t} \mathrm{FFB} \cdot \mathrm{ha}^{-1}$ compared to mineral fertilisers used at the same rate. This 10 t.ha $^{-1}$ compost-based fertiliser management halved the cost of fertilisers compared to the same nutrients supplied with mineral fertilisers only. The study showed an increase in fertiliser efficiency of $+66 \%$, $+37 \%,+20 \%$ and $+20 \%$ for compost compared to urea, rock phosphate, muriate of potash, and dolomite, respectively (Tohiruddin and Foster, 2013). However, a compost rate of around $10-15 \mathrm{t}^{-h a^{-1}} \cdot \mathrm{yr}^{-1}$ is much more than the amount available at the plantation scale. The compost is hence a limited and precious resource. How to make then the best use of compost ingredients and of the compost itself?

The process of composting is complex as it is influenced by a wide range of variables. Moisture, temperature and aeration are very sensitive factors so that compost quality can be fluctuating. While the composting process proved to be efficient in reducing the amount of waste, the efficiency of nutrient recycling (recovery ratio) is not always optimised. The environmental performance of POME and EFB co-composting was stressed by Stichnothe and Schuchardt (2010), when the recovery ratio is near $100 \%$ for every chemical element, but in open composting systems, rainwater dilution, leaching of effluents and volatilisation can result in the loss of $35 \%$ of total nitrogen and up to $70 \%$ of potassium (Salètes et al., 2004a,b). Minimising volatilisation and leaching through better POME uptake and leachate recycling are necessary to improve the agronomic value of compost and the environmental footprint of palm oil production. Compost-based fertiliser management is still new in the oil palm sector and many questions are still pending. Amongst research topics, the specific kinetics of various compost compositions (nutrient release rates) and their impacts on the soil quality (biological activity, physical characteristics, organic matter content, root density, CEC, etc.) are paramount in order to ensure the absorption efficiency of each element. Many factors need to be taken into consideration and further investigated in order to improve both compost composition and global recycling processes and to develop optimal strategies combining mineral and organic fertilisers. Such strategies would need to integrate research results on the most efficient compost use regarding the crop age, the soil type, the rates, the interactions with mineral complements, and the potential long-term effect on soil quality. Research is also needed in order to investigate trade-offs in terms of other coproduct uses and environmental and economic costs of application according to processes, applied doses and distances from the compost unit. The agro-economic optimum needs to be calculated at the plantation scale, taking into account that compost is a limited resource. Better estimates of the crop needs and reducing losses with the right time and forms of nutrient applications are also concomitant factors that need to be accounted for in order to improve soil quality in the longterm and to preserve the environment.

\section{The beetle disillusion}

The rhinoceros beetle Oryctes rhinoceros L. 1758 (Coleoptera: Scarabaeidae) is one of the major pest affecting oil palms in Southern and South-East Asia and the western pacific islands (Corley and Tinker, 2016; Howard et al., 2001). Damages are caused by the adult feeding on the palm crown and the apex. During the immature stage of oil palm plantations, a large amount of decaying organic matter is available from the previous stand, i.e. former palm stipes felled and left over in the field. This decaying oil palm is a highly suitable habitat for breeding sites (palm residues in windrows, empty fruit bunches...). O. rhinoceros affects immature palms for 3 to 4 years after planting by reducing growth and then yield; severe single attacks can also cause the death of the palm.

In South-East Asia, phytosanitary measures such as burning must be avoided because of their environmental impacts and in accordance with best practice recommendations such as RSPO principles and criteria (Principles \& Criteria 4.5 and 4.6, 2013). Either preventive or curative, Oryctes control was originally based on chemical treatments. However, several insecticides used for management and eradication also raise critical environmental and health concerns. Biopesticide tracks have been investigated and commercial strains are now available such as Metarhizium anisopliae (Metchnikoff) Sorokin, 1883, which has been successfully tested in the field as integrated to pheromone traps (Cik Mohd Rizuan et al., 2016). The O. rhinoceros nudivirus (Nudiviridae) has also a potential to reduce $O$. rhinoceros population and damages by adult infections and releases to contaminate the breeding sites (Bedford, 2013).

In 1997-2001, a selective trapping was developed in collaboration between CIRAD, IOPRI and INRA using synthetic attractants (Purba et al., 2000). The aggregation pheromone, i.e. attracting both males and females, ethyl 4-methyloctanoate (E 4-MO), which is produced by $O$. rhinoceros males, leads to substantial captures of adults, both males and females (Hallett et al., 1995). A dose/response effect was found: the higher the dose, the larger the captures. In the field, empty fruit bunches (EFB) attraction combined with the pheromone (acting as synergist) resulted in catches 2 to 4 times larger than with pheromone alone. Up to date, no synthetic synergists are able to replace EFB. The trap has been further improved by using a $2 \mathrm{~m}$ high PVC trap, which allowed for $30 \%$ more captures without any use of water or insecticide (Morin et al., 2001); this trap has a large capacity and can remain in place for several months, as long as the attractant does not run out.

The use of pheromone traps allows for reducing pest pressure without the use of toxic insecticides. Oehlschlager (2005) reports that a trapping rate of one pheromone lure per 2 ha reduced oil palm damage by more than $90 \%$, while being less expensive and more effective than chemical control practices. In other cases, however, trapping may not be sufficient to control O. rhinoceros population (Moore, 2011) 
and an assessment of the efficiency and cost of the trapping method in immature plantations compared to a conventional chemical control is still needed. Pheromone traps attract beetles and hence affect the palms at the vicinity of the traps, which can also enhance the pressure up to a certain point. Are those beetles damaging palms receptive to the pheromone or not? Which fractions of the beetle population go to or ignore the traps to go and feed on palms? Can trapping actually help to control the pest in a satisfactory way alone or could it have a vicious counterproductive attraction?

Allou et al. (2008) demonstrated that synthetic pheromone and EFB as the co-attractant mimic Oryctes monoceros reproduction sites only, where males emit this specific aggregation pheromone. Immature females or those having just laid eggs need to feed on fresh palm tissue to initiate a new oogenesis process and are hence not attracted by the pheromone lure. Consequently, trapping can only have a partial effect in attracting insects and reducing their damage (Allou et al., 2008). Moreover, a trial was conducted in Indonesia, in order to investigate the spatial correlation between the resident population, pheromone traps and damages on palms (Beaudoin-Ollivier et al., 2007). It is commonly assumed that the attraction potential of the traps depends on $O$. rhinoceros flight abilities and is influenced by landscape configuration. The study compared infestation in an immature plantation when trapping is launched either several months before planting or right at the time of planting. It confirmed the importance of the spatial configuration to address the efficiency of the trapping control. However, more knowledge on dispersal abilities is still needed to refine recommendations in order to further improve these biological control practices.

In conclusion, pheromone traps combined with EFB cannot be used alone as a pest control but may be a useful tool in order to detect and monitor the spread of the beetles (Moore, 2011). Combined with phytosanitary measures, such as the spreading of bio-pesticide on beetle breeding sites, pheromone trapping may help to keep $O$. rhinoceros population at an acceptable economic level within an integrated pest management strategy. Further studies are still needed to further improve and promote such bioregulation strategies.

\section{The rat, the barn owl and the leopard cat}

Rodent pests are a major source of crop damage worldwide, hereby highly impacting food security (Singleton et al., 2010; Stenseth et al., 2003). In South-East Asia, rats are invasive pests in oil palm plantations, causing significant damages (Turner and Gillbanks, 2003; Wood and Liau, 1984). Estimated potential loss may reach up to $10 \%$ of the production (Liau, 1990; Wood and Chung, 2003). Rats feed predominantly on the pericarp of oil palm fruit, whether directly on the fruit bunches on the palms or on loose fruit that fall to the ground when ripe; they are also found to eat apical tissues of oil palm seedlings in the nursery, as well as the petiole bases of immature palms; in addition, they also supplement their diet by feeding on the pollinating weevil Elaeidbobius kamericus, thereby affecting pollination success and fruit setting (Chiu et al., 1985; Chung, 2013; Wood, 1976). In oil palm plantations in South-East Asia, three species are dominant and represent

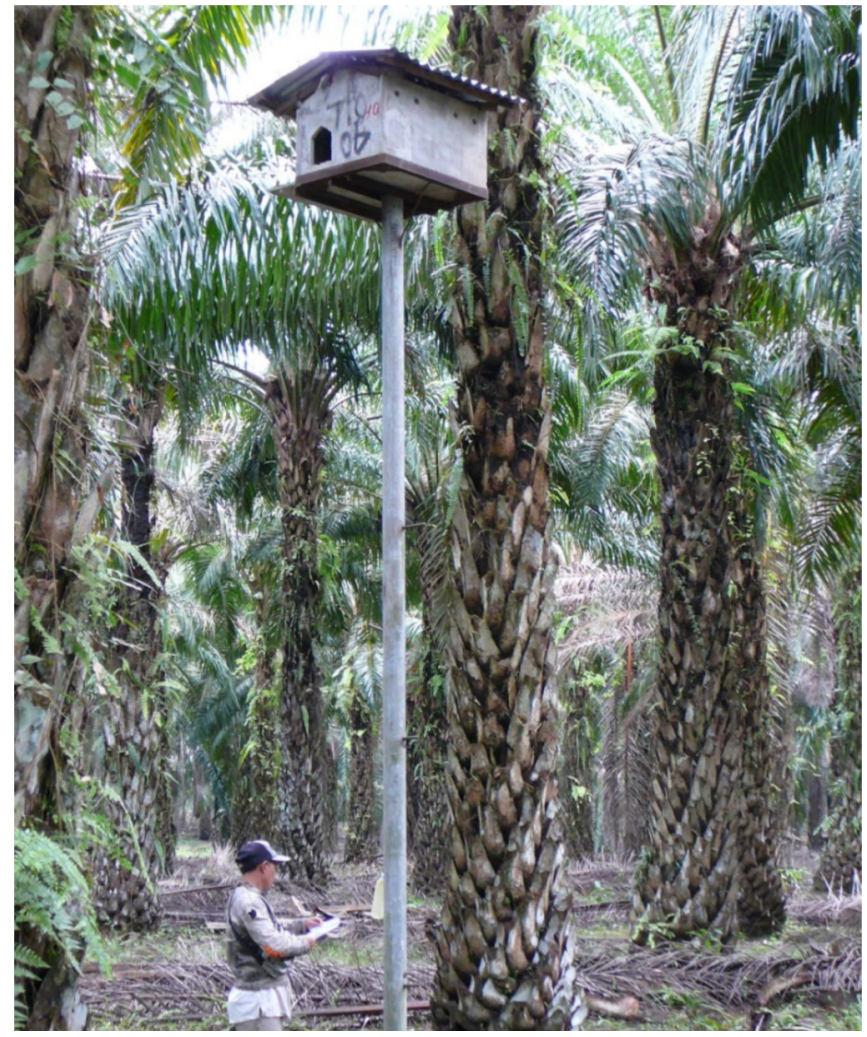

Fig. 4. A nest box for barn owls (Tyto alba) in oil palm plantation, 2010, Indonesia, Aude Verwilghen (C)irad.

major pests for the crop (Corley and Tinker, 2016; Liau et al., 1993; Wood and Chung, 2003):

- the Malaysian field rat, Rattus tiomanicus Miller;

- the ricefield rat, Rattus argentiventer Robinson and Kloss;

- the oriental house rat, Rattus tanezumi Temminck (synonym: Rattus rattus diardii Jentink).

In Malaysia and Indonesia, rat control originally relied on field treatment using anticoagulant rodenticides to maintain rat population at an acceptable level (cost of losses versus cost of control). However, rodenticide use is expensive (Wood and Chung, 2003) and can indirectly poison non-target species such as rat predators (Duckett, 2008; Naim et al., 2011). Moreover, rats have become more resistant to rodenticide following long-term exposure (Andru et al., 2013; Chia, 2005). Biological control of rodent pests is an interesting alternative to rodenticide treatment, from both biodiversity conservation and economic points of view. Enhancing barn owl (Tyto alba) populations into oil palm plantations for rat control was first developed in West Malaysia in the late 1970s, and provision of nest boxes within plantation led barn owl population to rapidly build up (Duckett, 1976; Lenton, 1980). It is now widely practiced by large oil palm companies in Malaysia and Indonesia (Fig. 4), in combination with rodenticide treatment or as the sole approach to rat control (Wood and Chung, 2003). The barn owl has long been reported to be effective in controlling rats in oil palm plantations (Duckett, 2008; Ho and Teh, 1997; Hoong and Hoh, 1992; Lenton, 1980). However, the actual impact of barn owl on rat population dynamics remains inconclusive since not clearly evidenced by relevant 


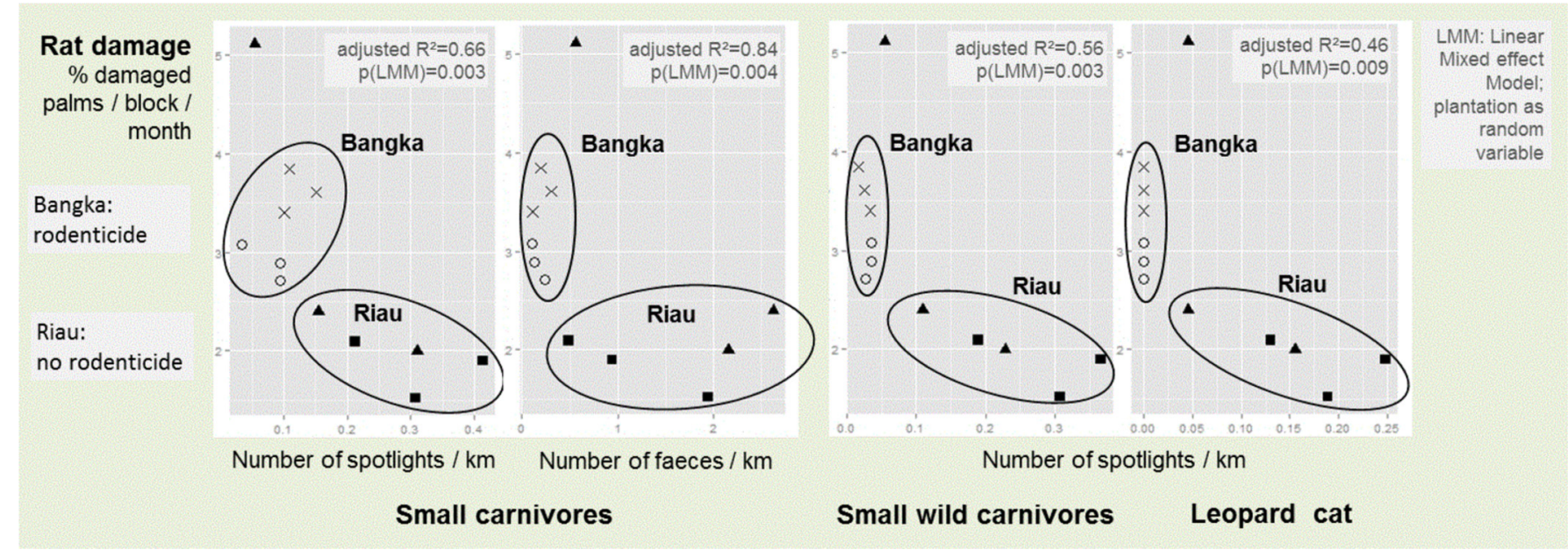

Fig 5. Relationship between estimated rodent damage and estimated small carnivores abundance in Riau and Bangka plantations. One point represent one year (from 2010 to 2012) on one plantation. Small carnivore community include domestic cats, small wild carnivores exclude domestic cats, Source: Verwilghen et al., 2016a.

protocols (Wood and Chung, 2003). It is unlikely that barn owls keep rat populations at low numbers on their own when rat infestation is very high (Chia et al., 1995; Khan, 2004). Rodent pest management in agricultural landscape is a complex issue where prey(s), predator(s), practices and landscape are in interaction, as suggested by the multi-factor hypothesis for rodent population dynamics (Krebs, 2013). Within the assemblage of rat predators, small carnivores ${ }^{6}$ such as felids, civets and mongooses may also contribute to rodent population regulation (Koh and Gan, 2008; Rajaratnam et al., 2007; Scott et al., 2004). However, persistence of small carnivores within oil palm plantations, their habitat uses, their diets and contributions to rodent control have been poorly investigated.

A study ${ }^{7}$ was conducted in Indonesia, over three consecutive years (2010-2012), aiming to investigate further the contribution of small carnivores in rat control in oil palm plantations in relation with other factors such as agricultural practices (notably rodenticide use) and landscape characteristics (Verwilghen, 2015; Verwilghen et al., 2016a,b). The research work was carried out in mature oil palm plantations located in Riau and Bangka provinces of Sumatra. In both areas, barn owls have been successfully introduced. In Riau, rat populations have been kept at an acceptable level without the use of rodenticide for more than 10 years. In Bangka, on the

\footnotetext{
${ }^{6}$ The term "small carnivores" is used herein for small-bodies (weighing $<15 \mathrm{~kg}$ ) members of the order Carnivora as categorised by IUCN (Schipper et al., 2008), to which we also include small felids and small-to-medium-size canidae such as dholes (Cuon alpinus) and foxes.

${ }^{7}$ The research study was initiated by CIRAD (Agricultural Research for Development, France), UFC (University of Franche-Comté, France) and SMARTRI (SMART Research Institute), in collaboration with CBGP (Center for Biology and Management of Populations, France), RCB-LIPI (Indonesian Institute of Sciences, Research Center for Biology) and MNHN (Muséum national d'histoire naturelle, France).
}

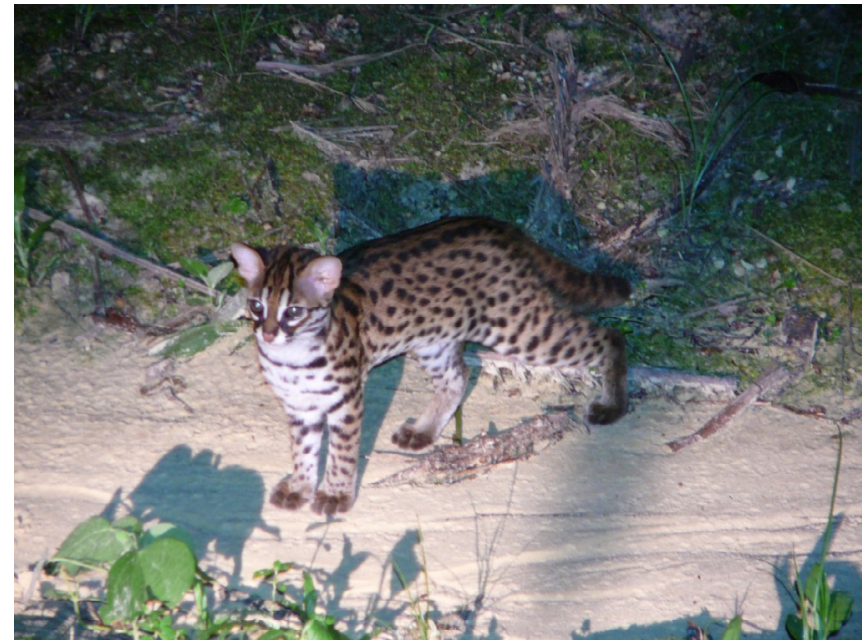

Fig. 6. A leopard cat (Prionailurus bengalensis) foraging in an oil palm plantation during night time, 2012, Indonesia, Aude Verwilghen (c) Cirad.

contrary, intensive rodenticide applications could not prevent high levels of rat damage. What can we learn from the analysis of rat predators' community that might explain the contrasted efficiency of rat control?

These two contrasted systems, namely Riau and Bangka, were compared in terms of predators' community (barn owls and small carnivores) abundance and/or diet. Using a kilometric abundance index yielded from spotlight and faeces counts, field investigations showed that small carnivores were much more abundant in Riau than in Bangka (the index was 2 to 10 times higher in Riau), and that small carnivore abundance was negatively correlated with rodent damage (Fig. 5). In particular, the leopard cat (Prionailurus bengalensis) (Fig. 6) was the dominant species encountered in Riau (about $62 \%$ of wild small carnivores observed during spotlight counts), whereas it was absent from Bangka. Moreover, the diet of the small carnivore community, as assessed from faeces collected 
in the field, relied more on vegetable food in Bangka compared to Riau, thereby reflecting differences in the small carnivore community composition or behavior between the two areas. For barn owls, analysis of nest boxes occupancy did not prove that barn owl population in Bangka was lower than in Riau. However, analysing the content of barn owls' pellets and the number of eggs laid in nest boxes, it was found that:

- the diet of barn owls in Bangka was more diversified and had a slightly lower proportion of rats compared to Riau; - barn owl breeding season was limited to one peak in Bangka compared to two peaks in Riau, thereby probably leading to a lowest food requirement in Bangka.

The most probable explanation of a restricted breeding season in Bangka is related to the effects of secondary intoxication from rodenticide, as suggested by results from Salim et al. (2014) and Taylor (1994). In Bangka, reduced hunting success and food intake by barn owls could be caused by sub-lethal effects of rodenticide interfering with locomotion (Stone et al., 2003). To conclude, the rat prey intake by barn owls and small carnivores tends to be lower in Bangka than in Riau. These findings support the hypothesis that, in Riau, the abundance of small carnivores and notably of leopard cats probably plays a key role in rat control, whereas, in Bangka, predator community seems not suitable (in terms of composition, abundance and diet) to ensure an efficient biological control of rat population. What could be improved in order to favour a larger development of predator community?

It is commonly assumed that the composition and distribution of a given predator community is influenced by landscape configuration (Delattre et al., 1992; Giraudoux et al., 1997; Lidicker, 2000). The spatial distribution of small carnivores within oil palm plantations and its correlation to habitats was thus further investigated, with a view to suggesting appropriate land use for small carnivore persistence within oil palm plantations. During nighttime (spotlight count), there was no specific attractive effect of forest habitat and oil palm plantation edge for either the leopard cat or the common palm civet (Paradoxurus hermaphroditus), which were both encountered deep within the oil palm habitat, whereas the Malay civet (Vivera tangalunga) was always observed at the edge of the oil palm habitat. At the community level, the analysis of faeces' spatial distribution (thereby reflecting both day and night activity from various species) showed an attractive effect of forest and oil palm edge habitats. These results support the hypothesis that the oil palm habitat may be suitable for some wild small carnivore species such as the leopard cat, where they supposedly forage at night, but that most species still need forest habitat for their survival in oil palm landscapes.

The whole study (Verwilghen, 2015) deciphered some agroecological mechanisms and practices involved in the biological control of rodents in palm plantations. It suggested that the efficiency of biological control would depend not only on the presence of a single predator, the barn owl, but rather on an assemblage of predators, including small carnivores. Hence, the settlement of barn owls within the oil palm plantations is not sufficient and must be associated with the provision of appropriate habitats for other rat predators, such as creating suitable rest sites within oil palm habitat and retaining forest habitat for the long-term persistence of small carnivores within oil palm landscapes (Chua et al., 2016; Jennings et al., 2015; Mudappa et al., 2007; Rajaratnam et al., 2007). The comparison between two contrasted agroecosystems (Riau and Bangka) also suggested that the long-term rodenticide treatment may have the opposite effect to the one originally intended, and that it can hardly go in hand with an effective biological control (e.g. indirect intoxication of natural predators). In order to promote bioregulation of rats by their natural predators, palm oil producers should therefore adapt agricultural practices (e.g. reducing/avoiding rodenticide use, managing understorey vegetation) and favour appropriate land use and landscape management, thereby enhancing the persistence of rat predators such as small carnivores within the oil palm habitat.

This study supports the hypothesis that enhancing biodiversity (a larger number of rat predators species) in oil palm plantations may improve the provision of ecosystem services, such as biological pest control, that are beneficial to oil palm management; it is a win-win strategy for both conservation and production. Further research work is still needed to provide more accurate recommendations notably on the landscape shaping and habitat fragmentation thresholds for leopard cats and other predators, as well as on limitations of rodenticide treatments and their negative secondary effects.

\section{Towards an agroecological control of the root caterpillar?}

In South-East Asia, oil palm expansion has increasingly occurred on peat soils due to land pressure (Afriyanti et al., 2016; Page et al., 2011). Tropical peatland is one of the largest global long-term repositories of terrestrial organic carbon, with the greatest extent (about $247,778 \mathrm{~km}^{2}$ ) and amount of carbon stored (about $68.5 \mathrm{Gt}$ ) in South-East Asia (specifically Indonesia and Malaysia) (Page et al., 2011). The conversion of peat land forest to agricultural land requires dense drainage, which leads to increased surface peat aeration, decomposition and carbon losses, and may turn peat ecosystem from a net carbon sink to a net carbon source (Page et al., 2011). Besides the issue of carbon loss, a too deep drainage may cause irreversible change in the water table, potentially leading to peat subsidence, indirect effects at the watershed level and potential subterranean fires. Hence, good practices for the management of oil palm plantations on peat soils require to actively manage the water table (RSPO P\&Cs $2013^{8}$ ).

Peat cultivation also poses further challenges. Pest pressure can be higher than on mineral soil. The moth Sufetula sunidesalis Walker (Lepidoptera: Crambidae: Spilomelinae) is a root mining insect damaging oil palm root system, which is a limiting factor of root development and yield in both Indonesia and Malaysia (Desmier de Chenon, 1975; Wahyu et al., 2001). The highly mobile caterpillar attacks the tender tissues of the primary root tip to feed and develop. It penetrates the apex and moves from root to root to feed, remaining inside the gallery only for short periods to continue and complete its development. Severely attacked root system can be observed

\footnotetext{
${ }^{8}$ Roundtable on Sustainable Palm Oil guidelines: http://www.rspo. org/key-documents/certification/rspo-principles-and-criteria, consulted on 28.1.2017.
} 

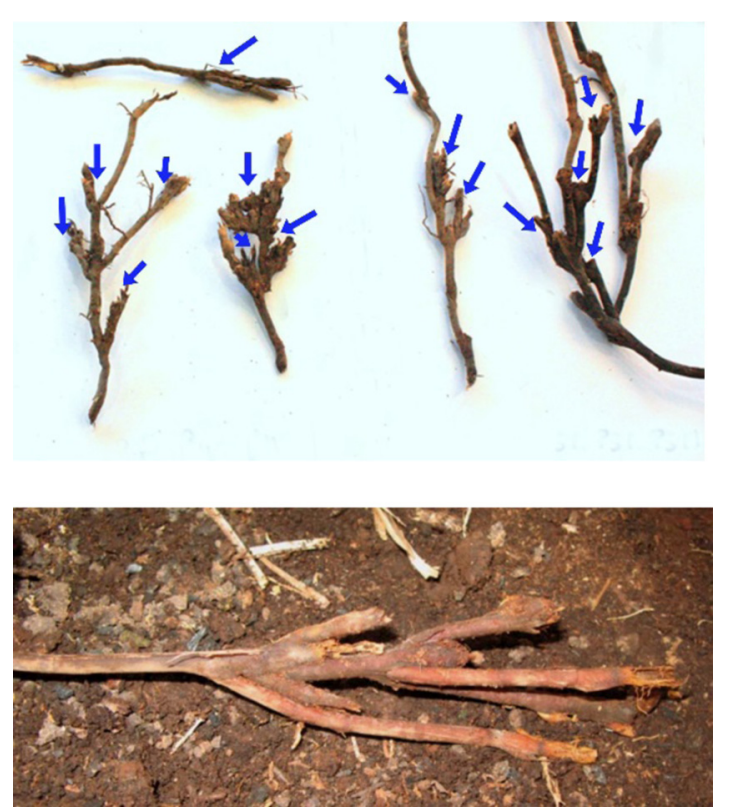

Fig. 7. Oil palm roots showing traces of successive reiterations right from an early stage due to Sufetula attack, Xavier Bonneau @Cirad.

when oil palms are grown on peat soil, whereas the oil palms display a relatively healthy root system in an infested area on mineral soil (Beaudoin-Ollivier et al., 2011). This pest pressure on the root systems of oil palms in plantations on peat has a negative effect on the physiology of the palm through progressive exhaustion. Indeed, when caterpillars attack the roots, these roots generate new apices nearby the point of attack and the palm spends too much energy regenerating a continually attacked root system to the detriment of the aerial parts (fronds responsible for photosynthesis and bunches ensuring yields) (Fig. 7). The balance of carbon and energy partitioning between the different organs of the palms is thus changed (Bonneau et al., 2007).

Insecticide application has been tested using Rope $25 \mathrm{EC}$ but only repeated applications might provide some protection and has not proven to be very effective (Wahyu et al., 2001). The caterpillar is difficult to reach with the pesticides when it is located inside the root apex. Moreover, the quantities of insecticide needed to achieve a significant reduction in damage would be excessive and such a phytosanitary method is not economically and environmentally sustainable (residues in peat and water).

To date, the alternative to insecticides are phytosanitary practices that would imply to clean plots by removing all vegetation or debris likely to provide shelter to $S$. sunidesalis adults during daytime. In coconut plantations, it was observed that Sufetula adults usually shelter in ferns, whereas they do not stay in the mosses that are left over when the vegetation cover is cleared (Bonneau et al., 2007). This involves, however, constraints in terms of labor and costs, and requires the burning of debris such as dry fronds fallen to the ground, which goes against zero burning policies that are in force in most producing countries?

\footnotetext{
${ }^{9}$ See for instance the ASEAN Policy on Zero Burning 2003.
}

Agroecological alternatives could be developed pursuing two different tracks. First, as Sufetula sp. is harmful for oil palms growing on peat soil, it would be interesting to take advantage from the natural water load of the soil and optimise water table management to reach several targets. The active management of water table could be adjusted to a minimal depth in order to minimise the soil depth where larvae can develop. In case of a severe attack, the contaminated plantation blocks could also be shortly flooded to reduce the level of the caterpillar population. This technique would be repeated once or twice a year depending on the pest pressure (Wahyu et al., 2001). At the same time, this would give further incentive to actively manage the water table in order to avoid too deep drainage and irreversible consequences.

Second, studies have been implemented so as to study the behavior, chemical ecology and biological enemies of $S$. sunidesalis in order to establish the baseline for a targeted biological control (Lavogez, 2012). Studying relation between caterpillar/moth and host plant allowed for the discovery of two molecules possibly constituting a kairomone emitted by root apex. These molecules might be synthetized in order to develop a new biological control based on diffusers and traps. Moreover, indigenous nematodes leading to a significant mortality rate in S. sunidesalis larvae have been discovered in Sumatra plantations. Such preliminary results (Lavogez, 2012) will feed new agroecological practices to fight $S$. sunidesalis through biological control means.

\section{Discussion and conclusion}

Enhancing agroecosystem properties through the development and implementation of agroecological practices can generate high palm oil yields while reducing external inputs such as mineral fertilisers and pesticides. It is of paramount interest to reduce such external inputs as much as possible, given the large environmental burdens they may carry along accounting for emissions and impacts both upstream the supply chain and in the field. The recycling of oil palm and palm oil co-products at both the plantation and mill stages makes it possible to reduce the amounts of mineral fertilisers without depleting the soil nutrient resources or stressing the palms. Our story about the impact of palm empty fruit bunches application on soil quality showed that the use of these coproducts, in particular on fragile soils, could help to maintain or improve soil nutrient resources, soil permeability or soil biological activity. At the same time, the recycling of coproducts reduces the polluting emissions and environmental impacts related to waste treatments. The co-composting of empty bunches together with palm oil mill effluent drastically reduces methane emissions during the conventional anaerobic effluent digestion.

Altogether, the stories about recycling, with the examples of empty bunches and compost, highlight the great potential in the use and valuing of the numerous and diversified palm oil co-products. However, they also show some potential problem shifting and trade-offs that need to be considered. First, the oil palm co-products recycled in the field can contribute to some environmental issues, such as the provision of habitats to pest such as $O$. rhinoceros or 
S. sunidesalis, in South-East Asia notably, or Fusarium in Africa, or the high nitrogen leaching during the palm immature phase (Pardon et al., 2016). Second, there may be competitive uses for co-products either as amendment brought back to the field or as bioenergy feedstock exported. It is hence necessary to assess and compare various options considering relative beneficial as well as detrimental impacts all along the supply chains, i.e. accounting for potential substitutions or problem shifting across a range of environmental impacts. Life Cycle Assessment (LCA) allows for assessing various environmental impacts of a product over the whole supply chain. This multicriterion approach does not emphasize any one impact but pinpoints the greatest impacts and their origins at certain production stages. The necessary trade-offs and arbitrations can thus be documented (Bessou et al., 2016). However, impacts related to covariations in the connected physico-chemical and biological soil properties and soil functions are still hardly addressed in LCA (Stichnothe and Bessou, 2017). Potential improvement of soil quality or protection from soil erosion due to the organic amendments are not yet properly part of the life cycle impact assessment due to still limited knowledge in order to model all potential correlated processes and impacts. In order to design the best environmental friendly scenarios of residues and global plantation managements, a proper modelling of impact onto the soil is though crucial (Stichnothe and Bessou, 2017). More research is needed conveying soil, agroecological and LCA scientists in order to better understand and model the involved mechanisms and develop further efficient agroecological systems.

Some trade-offs may also be critical when analysing mechanisms of pest biological control. The use of pheromone to trap pests has proven useful in some plantations but merely sufficient. The net benefit over detrimental side effects and in synergy with complementary management practices need to be optimised based on a better understanding of the beetle population dynamics and on the influence of the plantation configuration and management practices. In order to improve or develop biological control strategies, there is still a need for a more comprehensive understanding of the underlying multifactor mechanisms that may involve complex networks of prey and predators and depend on both the practices within the palm plantation and the landscape management beyond the palm plantation edges.

The story about "the rat, the barn owl and the leopard cat" clearly shows that preserving the benefits of auxiliary predators in oil palm agroecosystems could maximise the ecosystem services of natural pest suppression, to the benefit of both production and conservation. Hence, wildlife-friendly management practices can go in hand with enhancement of yields according to the concept of agroecology and ecological intensification (Altieri, 1999; Chevassus-Au-Louis, 2006; Griffon, 2013). Foster et al. (2011) stressed the importance of conserving biodiversity and ecosystem processes within the oil palm habitat itself. However, little is known about the effect of local management practices and landscape design on biodiversity and its relation to ecosystem services or disservices (Tscharntke et al., 2005; Zhang et al., 2007), specifically in the oil palm agroecosystems (Foster et al., 2011; Savilaakso et al., 2014). To our knowledge, little research on this topic has been carried out in oil palm landscapes; the BEFTA project (Biodiversity and Ecosystem Function in Tropical Agriculture; http://oilpalmbiodiversity. $\mathrm{com} /$ ) and the biodiversity enrichment experiment EFForTSBEE (Teuscher et al., 2016) being valuable exceptions.

\section{References}

Abu Bakar R, Darus S, Kulaseharan S, Jamaluddin N. 2011. Effects of ten year application of empty fruit bunches in an oil palm plantation on soil chemical properties. Nutr Cycl Agroecosyst 89: 341-349.

Achten WMJ, Verchot LV. 2011. Implications of biodiesel-induced land-use changes for $\mathrm{CO} 2$ emissions: case studies in tropical America, Africa, and Southeast Asia. Ecol Soc 16(4). Available from http://www.ecologyandsociety.org/vol16/iss4/art14/ (verified 7 February 2017).

Afriyanti D, Kroeze C, Saad A. 2016. Indonesia palm oil production without deforestation and peat conversion by 2050. Sci Total Environ 557-558 : 562-570.

Ahmad MN, Mokhtar MN, Baharuddin AS, et al. 2011. Changes in physicochemical and microbial community during co-composting of oil palm frond with palm oil mill effluent anaerobic sludge. BioResources 6(4): 4762-4780.

Allou K, Morin JP, Kouassi P, Hala N'klo F, Rochat D. 2008. Sex ratio and female sexual status of the coconut pest, Oryctes monoceros (Coleoptera: Dynastidae), differ in feeding galleries and pheromone-baited traps. Bull Entomol Res 98: 581-586.

Altieri MA. 1999. The ecological role of biodiversity in agroecosystems. Agric Ecosyst Environ, 74(1-3): 19-31.

Andru J, Cosson JF, Caliman JP, Benoit E. 2013. Coumatetralyl resistance of Rattus tanezumi infesting oil palm plantations in Indonesia. Ecotoxicology 22: 377-396.

Baharuddin AS, Kazunori N, Abd-Aziz S, et al. 2009. Characteristics and microbial succession in co-composting of oil palm empty fruit bunch and partially treated palm oil mill effluent. Open Biotechnol J 3: 92-100.

Banabas M. 2007. Study of nitrogen loss pathways in oil palm (Elaeis guineensis Jacq.) growing agro-ecosystems on volcanic ash soils in Papua New Guinea: a thesis presented in partial fulfillment of the requirements for the degree of Doctor of Philosophy in Soil Science at Massey University, Palmerston North, New Zealand.

Beaudoin-Ollivier L, Bergoin M, Jacquemard JC, Fuad M. 2007. Better knowledge of oil palm pests for an IPM approach. Poster presented at International Conference on Oil Palm and Environment (ICOPE 2007), 15-16 November 2007, Nusa Dua Bali, Indonesia.

Beaudoin-Ollivier L, Lazwar A, Bonneau X, Ribeyre F. 2011. Importance of Sufetula sp. attacks on the root system of the oil palm growing on peat soil (Elaeis guineensis Jack) in Sumatra. Poster presented at PIPOC International Palm Oil Congress, 15-17 November 2011, Kuala Lumpur, Malaysia.

Bedford GO. 2013. Biology and management of palm dynastid beetles: recent advances. Annu Rev Entomol 58: 353-372.

Bernal MP, Paredes C, Sanchez Monedero MA, Cegarra J. 1998. Maturity and stability parameters of composts prepared with a wide range of organic wastes. Bioresour Technol 63: 91-99.

Bessou C, Pardon L. 2017. Environmental impacts of palm oil products: What can we learn from LCA? Indonesian J Life Cycle Assess Sustain 1: 1-7.

Bessou C, Chase LDC, Henson IE, et al. 2014. Pilot application of PalmGHG, the roundtable on sustainable palm oil greenhouse gas calculator for oil palm products. J Clean Prod 73: 136-145. 
Bessou C, Basset-Mens C, Benoist A, et al. 2016. In: Torquebiau E., ed., Manley D. (trad.), Cowan P. (trad.). Climate change and agriculture worldwide. Heibelberg: Springer, 263-275. ISBN 978-94-017-7460-4

Bonneau X, Husni M, Beaudoin-Ollivier L, Susilo J. 2007. Controlling Sufetula spp.: a coconut insect pest on peat soils. Exp Agric 43: 289-299. doi: 10.1017/ S0014479707005017.

Brussaard L. 2012. Ecosystem services provided by the soil biota. Soil ecology and ecosystem services. Oxford, UK: Oxford University Press, 45-58.

Budianta D, Halim A, Midranisiah PKS, Bolan NS. 2010. Palm oil compost reduces aluminium toxicity thereby increases phosphate fertiliser use efficiency in Ultisols. 19th World Congress of Soil Science, Soil Solutions for a Changing World. Brisbane, Australia. pp. 221-223.

Bukhari NA, Loh SK, Nasrin AB, et al. 2014. Composting of oil palm biomass: current status in Malaysia. Presented at the National Seminar on Palm Oil Milling, Refining, Environment and Quality (POMREQ).

Caliman JP, M Budi, Salètes S. 2001. Dynamics of nutrient release from empty fruit bunches in field conditions and soil characteristics changes. Proceedings of the 2001 PIPOC International Palm Oim Congress, MPOB, Bangi (2001) pp. 550-556.

Carron MP, Pierrat M, Snoeck D, et al. 2015a. Temporal variability in soil quality after organic residue application in mature oil palm plantations. Soil Res 53, 205-215.

Carron MP, Auriac Q, Snoeck D, et al. 2015b. Spatial heterogeneity of soil quality around mature oil palms receiving mineral fertilization. Eur J Soil Biol 66: 24-31.

Ceglie FG, Adbelrahman HM. 2014. Ecological intensification through nutrients recycling and composting in organic farming. In: Maheshwari DK, ed. Composting for sustainable agriculture. Sustainable development and biodiversity 3, Springer, 2-22.

Chakraborty A, Chakrabarti K, Chakraborty A, Ghosh S. 2011. Effect of Long-Term Fertilizers and Manure Application on Microbial Biomass and Microbial Activity of a Tropical Agricultural Soil. Biology and Fertility of Soils 47(2): 227-33.

Chase LDC, Henson IE. 2010. A detailed greenhouse gas budget for palm oil production. Int J Agric Sustain 8(3): 199-214.

Chavalparit O, Rulkens WH, Mol APJ, Khaodhair S. 2006. Options for environmental sustainability of the crude palm oil industry in thailand through enhancement of industrial ecosystems. Environ Dev Sustain 8(2): 271-287.

Chevassus-Au-Louis B. 2006. Biodiversité, un nouveau regard. Refonder la recherche agronomique. Groupe ESA (Ecole Supérieure d'Agriculture d'Angers) Angers, France, 101 p.

Chia TH. 2005. Rat control in oil palm plantations: A review. Planter 81(946): 15-26.

Chia TH, Lim JL, Buckle A. 1995. Barn owls for rat control on oil palm plantations - do they work? Planter 71(828): 109-117.

Chiew YL, Shimada S. 2013. Current state and environmental impact assessment for utilizing oil palm empty fruit bunches for fuel, fiber and fertilizer - A case study of Malaysia. Biomass Bioenerg 51: 109-124.

Chin MJ, Poh PE, Tey BT, Chan ES, Chin KL. 2013. Biogas from palm oil mill effluent (POME): Opportunities and challenges from Malaysia's perspective. Renew Sustain Energy Rev 26: $717-726$.

Chiu SB, Khoo KC, Mohd Yusof H. 1985. Extent of rat on Elaeidobius kamerunicus Faust, the pollinating weevil of oil palm. Planter 61: 101-112.

Choo YM, Muhamad H, Hashim Z, et al. 2011. Determination of GHG contributions by subsystems in the oil palm supply chain using the LCA approach. Int J Life Cycle Assess 16: 669-681. doi: 10.1007/s11367-011-0303-9.

Chua MA, Sivasothi N, Meier R. 2016. Population density, spatiotemporal use and diet of the leopard cat (Prionailurus bengalensis) in a human-modified succession forest landscape of Singapore. Mammal Res 61(2): 99-108.

Chung GF. 2013. Rat management in oil palm. In: Proceedings 4th IOPRI-MPOB International Seminar: existing and emerging pests and diseases of oil palm advances in research and management. Eds. Malaysia Palm Oil Board \& Indonesian Oil Palm Research Institute. Bandung, Indonesia 13-14 December 2012. Pusat Penelitian Kelapa Sawit, p. 407.

Cik Mohd Rizuan ZA, Noor Hisham H, Mohd Rozmi M, Nazihah Mohd S. 2016. The evaluation of solid substrate formulation of Metarhizium anisopliae var. major (M-SS), against Oryctes rhinoceros L. in young oil palm plantations. Planter 92(1081): 205-218.

Cock J, Kam SP, Cook S, et al. 2016. Learning from commercial crop performance: Oil palm yield response to management under well-defined growing conditions. Agric Syst 149: 99-111.

Comte I, Colin F, Grünberger O, Follain S, Whalen JK, Caliman J-P. 2013. Landscape-scale assessment of soil response to long-term organic and mineral fertilizer application in an industrial oil palm plantation, Indonesia Agric Ecosyst Environ 169: 58-68.

Conway G. 1996. The doubly Green Revolution: food for all in the twenty-first century. The doubly Green Revolution: food for all in the twenty-first century. UK: Comstock Publishing Associates.

Corley RHV, Tinker PB. 2016. The oil palm, Fifth edition. Wiley Blackwell Publishing, 639 p. doi: 10.1002/9781118953297.

Darmosarkoro W, Sutarta ES. 2002. Application of EFB compost on acidic soil in North Sumatra to increase soil bases and decrease aluminium. Proc. of the Agriculture Conference, International Oil Palm Conference 2002 (IOPC). Indonesian Oil Palm Research Institute (IOPRI), Nusa Dua Bali, Indonesia. pp. 464-470.

Delattre P, Giraudoux P, Baudry J, et al. 1992. Land use patterns and types of common vole (Microtus arvalis) population kinetics. Agric Ecosyst Environ 39: 153-169.

Desmier de Chenon R. 1975. Présence en Indonésie et Malaisie d'un lépidoptère mineur des racines du palmier à huile, Sufetula sunidesalis Walker et relations avec les attaques de Ganoderma. Oléagineux 30(11): 449-456.

Dislich C, Keyel AC, Salecker J, et al. 2016. A review of the ecosystem functions in oil palm plantations, using forests as a reference system. Biol Rev.

Donough CR, Witt C, Fairhurst TH. 2009. Yield intensification in oil palm plantations through best management practice. Better Crops 93: $12-14$.

Dubos B, Snoeck D, Flori A. 2016. Excessive use of fertilizer can increase leaching processes and modify soil reserves in two ecuadorian oil palm plantations. Exp Agric.

Duckett JE. 1976. Owls as major predators of rats in oil palm estates with particular reference to the barn owl (Tyto alba). Planter 52(598): 4-15.

Duckett JE. 2008. The expansion of range and population of the barn owl (Tyto alba javanica) in Peninsular Malaysia and in Sumatra and adjacent islands: A review and update on the current situation. Planter 84(994): 799-807.

FAO 2004. Fertilizer use by crop in Malaysia. FAO (Rome). http:// www.fao.org/docrep/007/y5797e/y5797e00.HTM.

Fitzherbert EB, Struebig MJ, Morel A, et al. 2008. How will oil palm expansion affect biodiversity? Trends Ecol Evol 23(10): 538-545. 
Foster H. 2003. Assessment of oil palm fertiliser requirements. In: Fairhurst TH, Hardter R, eds. Oil palm management for large and sustainable yields. Potash and Phosphate Institute, pp. 231-257.

Foster WA, Snaddon JL, Turner EC, et al. 2011. Establishing the evidence base for maintaining biodiversity and ecosystem function in the oil palm landscapes of South-East Asia. Philosophical Transactions of the Royal Society B. Biol Sci 366(1582): 3277-3291.

Francou C, Poitrenaud M, Houot S. 2005. Stabilization of organic matter during composting: Influence of Process and Feedstocks. Compost Sci Util.

Germer J, Sauerborn J. 2008. Estimation of the impact of oil palm plantation establishment on greenhouse gas balance. Environ Dev Sustain 10(6): 697-716.

Giraudoux P, Delattre P, Habert M, et al. 1997. Population dynamics of fossorial water vole (Arvicola terrestris Scherman): a land use and landscape perspective. Agr Ecosyst Environ 66(1): 47-60.

Goh K-J., Härdter R. 2003. General oil palm nutrition. Oil palm management large sustainable yields. Fairhurst, Härdter, eds. PPIPPIC-IPI Singa pp. 191-230.

Goh KJ, Po SB. 2005. Fertilizer recommendation systems for oil palm: estimating the fertilizer rates. In: Proceedings of MOSTA Best practices workshops-agronomy and crop management. Malaysian Oil Scientists' and Technologists' Association.

Griffon M. 2007. Pour des agricultures écologiquement intensives. L'Aube 2010 [2007].

Griffon M. 2013. Qu'est ce que l'agriculture écologiquement intensive ? Versailles : Éditions Quae, 220 p.

Guillaume T, Damris M, Kuzyakov Y. 2015. Losses of Soil Carbon by Converting Tropical Forest to Plantations: Erosion and Decomposition Estimated by $\delta^{13} \mathrm{C}$. Global Change Biol 21(9): 3548-60. doi: $10.1111 /$ gcb. 12907 .

Hallett RHA, Perez L, Gries G. 1995. Aggregation pheromone on coconut rhinoceros beetle; Oryctes rhinoceros (L.) (Coleoptera: Scarabaeidae). J Chem Ecol 21(10): 1549-1570.

Hansen S. 2007. Feasibility study of performing a life cycle assessment on crude palm oil production in Malaysia ( $9 \mathrm{pp}$ ). JT Int J Life Cycle Assess 12: 50-58.

Harsono SS, Grundmann P, Soebronto S. 2014. Anaerobic treatment of palm oil mill effluents: potential contribution to net energy yield and reduction of greenhouse gas emissions from biodiesel production. J Clean Prod 64: 619-627.

Henson IE. 2004. Modelling carbon sequestration and emissions related to oil palm cultivation and associated land use change in Malaysia. MPOB technology 27.

Ho CT, Teh CL. 1997. Integrated pest management in plantation crops in Malaysia: challenges and realities. In: Proceedings of the International Planters conference, Plantation Management for the 21st Century (Ed. Pushparajah E). Kuala Lumpur, Malaysia, 21-22 May 1997. Kula Lumpur: Incorporated Society of Planters pp. 125-149.

Hoong HW, Hoh CKY. 1992. Major pests of oil palm and their occurrence in Sabah. Planter 68(793): 193-210.

Howard FW, Moore D, Giblin-Davis RM, Abad RG. (2001) Insects on palms. Wallingford: CABI Publishing, $400 \mathrm{p}$.

Jennings A, Naim M, Advento AD, et al. 2015. Diversity and occupancy of small carnivores within oil palm plantations in central Sumatra. Indonesia Mammal Res 60(2): 181-188.

Karlen D, Mausbach M, Doran J, Cline R, Harris R, Schuman G. 1997. Soil quality: a concept, definition, and framework for evaluation. Soil Sci Soc Am J 61: 4-10.

Karlen DL, Ditzler CA, Andrews SS. 2003. Soil quality: why and how? Geoderma 114: 145-156.
Kavitha et al. 2016. Compost maturity test for Empty fruit bunch of palm oil industry solid waste. Consulté le mars 23. http:// saspublisher.com/wp-content/uploads/2013/08/SAJB-1398-101. pdf.

Khan MMH. 2004. Food habit of the leopard cat Prionailurus bengalensis (Kerr, 1792) in the Sundarbans East wildlife sanctuary, Bangladesh. Zoo's Print J 19(5): 1475-1476.

Koh LP, Gan LT. 2008. Beneficial biodiversity: a review on potentially beneficial reptile, bird and mammal species in oil palm plantations. Planter 84(984): 169-175.

Koh LP, Wilcove DS. 2008. Is oil palm agriculture really destroying tropical biodiversity? Conserv Lett 1(2): 60-64.

Krebs CJ. 2013. Population fluctuations in rodents. Chicago: University of Chicago Press.

Kurnia JC, Jangam SV, Akhtar S, Sasmito AP, Mujumdar AS. 2016. Advances in biofuel production from oil palm and palm oil processing wastes: A review. Biofuel Res J 3(1): 332-346.

Lake S, Rosenbarger A, Winchester C. 2016. Palm risk assessment methodology: prioritizing areas, landscapes, and mills. Washington: World Resources Institute.

Lal R. 2004. Soil carbon sequestration to mitigate climate change. Geoderma 123(1-2): 1-22.

Lavelle P, Barros E, Blanchart E, et al. 2001. SOM management in the tropics: Why feeding the soil macrofauna? Nutr Cycl Agroecosyst 61: 53-61.

Lavelle P, Decaëns T, Aubert M et al. 2006. Soil invertebrates and ecosystem services. Eur J Soil Biol 42: S3-S15.

Lavogez O. 2012. Comportement et écologie chimique de Sufetula sunidesalis (Lepidoptera : Crambidae : Spilomelinae), ravageur des racines du palmier à huile. Rapport de stage, Master 2, 67 p.

Lenton GM. 1980. Biological control of rats in oil palm by owls. In: Proceedings of the 5th International Symposium of Tropical Ecology "Tropical Ecology and Development" (Ed. Furtad, JI). Kuala Lumpur, Malaysia, 16-21 April 1979, pp. 615-621.

Liau SS. 1990. Rat population in oil palm replants and crop loss assessment (Malaysia). In: 3rd International Conference on Plant Protection in the Tropics, 20-23 Mar 1990. Genting Highlands, Pahang, Malaysia, 20-23 Mar 1990. Malaysian Plant Protection Society, Kuala Lumpur, pp. 8-18

Liau SS, Chung GF, Sim SC, Ho CT. 1993. Rat species composition and distribution in West Malaysian plantations (with particular reference to oil palm plantations). In: Basiron Y, Jalani S, Chang $\mathrm{KC}$, Cheah SC, Henson IE, Kamarudin N, et al., eds. Proceedings of the 1991 PORIM International Palm Oil Conference Progress, Prospects \& Challenges Towards the 21st Century, Module I Agriculture. Kuala Lumpur, 9-14 September 1991. Palm Oil Research Institute of Malaysia, Kuala Lumpur, pp. 511-516.

Lidicker WZ. 2000. A food web/landscape interaction model for microtine rodent density cycles. Oikos 91(3): 435-445.

Liew WL, Kassim MA, Muda K, Loh SK. 2006. Feasibility study on palm oil processing wastes towards achieving zero discharge. Available from http://www.arpnjournals.org/jeas/research_pa pers/rp_2016/jeas_0216_3659.pdf (verified 9 February 2017).

Mohammad N, Alam MZ, Kabbashi NA, Ahsan A. 2012. Effective Composting of Oil Palm Industrial Waste by Filamentous Fungi: A Review. Res Conserv Recycl 58: 69-78. doi: 10.1016/j. resconrec.2011.10.009.

Moore A. 2011. Update on the Guam coconut rhinoceros beetle eradication project. Accessed on 21 April 2014, http:/guamin sectes.net.

Moradi A, Teh Boon Sung C, Goh KJ, Husni Mohd Hanif A, Fauziah Ishak C. 2015. Effect of four soil and water conservation practices 
on soil physical processes in a non-terraced oil palm plantation. Soil Tillage Res 145: 62-71.

Morin JP, Sudharto PS, Purba Rolettha Y, et al. 2001. A new type of trap for capturing Oryctes rhinoceros (Scarabaeidae, Dynastinae), the main pest in young oil palm and coconut plantings. CORD, Coconut Res Dev 17(2): 13-22.

Mudappa D, Noon BR, Kumar A, Chellam R. 2007. Responses of small carnivores to rainforest fragmentation in the southern Western Ghats, India. Small Carn Conserv 36: 18-26.

Naim M, Hafidzi MN, Azhar K, Jalila A. 2011. Comparison of the breeding performance of the barn owl Tyto alba javanica under chemical and bio-based rodenticide baiting in immature oil palms in Malaysia. Dyn Biochem Process Biotechnol Mol Biol 5(2): 5-11.

OECD, FAO. 2013. Oilseeds and oilseed products. OECD-FAO Agricultural Outlook 2013. Paris: OECD Publishing.

Oehlschlager C. 2005. Current status of trapping palm weevils and beetles. Planter Incorporated Soc Planters 123-143.

Page SE, Morrison R, Malins C, Hooijer A, Rieley JO, Jauhiainen J. 2011. Review of peat surface greenhouse gas emissions from oil palm plantations in South-East Asia. International Committee on Clean Transportation (ICCT). In publication. Available from http://sa.indiaenvironmentportal.org.in/files/file/ICCT_PeatEmissions_Sept2011.pdf (verified 17 April 2016).

Paltseva J, Searle S, Malins C. 2016. Potential for advanced biofuel production from palm residues in Indonesia. Washington, DC: The International Council on Clean Transportation. Available from http://www. theicct. org/advanced-biofuel-productionfrompalm-residues-indonesia.

Papong S, Chom-In T, Noksa-nga S, Malakul P. 2010. Life cycle energy efficiency and potentials of biodiesel production from palm oil in Thailand. Energ Policy 38(1): 226-233.

Pardon L, Bessou C, Nelson PN et al. 2016. Key unknowns in nitrogen budget for oil palm plantations. A review Agron Sustain Dev 36(1): 1-21.

Pirker J, Mosnier A, Kraxner F, Havlík P, Obersteiner M. 2016. What are the limits to oil palm expansion? Glob Environ Change 40: 73-81.

Purba Rolettha Y, Desmier de Chenon R, Prawirosukarto S, morin JP, Rochat D. 2000. Effect of Oryctes rhinoceros pheromone (ethyl 4-methyloctanoate) diffusion rate on the size of pest catches. In: xxi International congress of entomology. 21, Foz do Iguaçu, Brésil, 20 Août 2000/26 Août 2000. In: Gazzoni DL, ed. EMBRAPA-Soja, SEB. Londrina: EMBRAPA, Résumé, 181. (Documentos Embrapa Soja, 143).

Rajaratnam R, Sunquist M, Rajaratnam L, Ambu L. 2007. Diet and habitat selection of the leopard cat (Prionailurus bengalensis borneoensis) in an agricultural landscape in Sabah. Malaysian Borneo J Trop Ecol 23: 209-217.

Reeves DW. 1997. The role of soil organic matter in maintaining soil quality in continuous cropping systems. Soil Tillage Res 43: 131167.

Reijnders L, Huijbregts MAJ. 2008. Palm oil and the emission of carbon-based greenhouse gases. J Clean Prod 16(4): 477482.

Rival A, Levang P. 2013. La palme des controverses : Palmier à huile et enjeux de développement. Versailles, France : Éditions Quæ.

Salètes S, Caliman JP, Raham D. 2004a. Study of mineral nutrient losses from oil palm empty fruit bunches during temporary storage. J Oil Palm Res 16(1): 11-21.

Salètes S, Siregar FA, Caliman JP, Liwang T. 2004b. Ligno-cellulose composting: Case study on monitoring oil palm residuals. Compost Sci Util 12(4): 372-382.
Salim H, Noor HM, Omar D, et al. 2014. Sub-lethal effects of the anticoagulant rodenticides bromadiolone and chlorophacinone on breeding performances of the barn owl (Tyto alba) in oil palm plantations. Slovak Raptor J 8(2): 113-122.

Savilaakso S, Garcia C, Garcia-Ulloa J, et al. 2014. Systematic review of effects on biodiversity from oil palm production. Environ Evidence 3(1): 4.

Schmidt JH. 2010. Comparative life cycle assessment of rapeseed oil and palm oil. Int J Life Cycle Assess 15(2): 183-197.

Schuchardt F, Darnoko D, Guritno P. 2002. Composting of empty oil palm fruit bunch (EFB) with simultaneous evaporation of oil mill waste water (POME). In: Proceedings. Bali, Nusa Dua.

Scott DM, Gemita E, Maddox TM. 2004. Small cats in human modified landscapes in Sumatra. Cat News 40: 23-25.

Shindo H, Hirahara O. Yoshida M, Yamamoto A. 2006. Effect of continuous compost application on humus composition and nitrogen fertility of soils in a field subjected to double cropping. Biol Fert Soils 42(5): 437-42.

Silalertruksa T, Bonnet S, Gheewala SH. 2012. Life cycle costing and externalities of palm oil biodiesel in Thailand. J Clean Prod 28:225-232. doi: 10.1016/j.jclepro.2011.07.022.

Singh G, Kow DL, Lee KH, Lim KC, Loong SG. 1999. Empty fruit bunches as mulch. In: Oil palm and the environment - a Malaysian perspective. Kuala Lumpur. Kuala Lumpur: Malaysian Palm Oil Growers'Council, pp. 171-183.

Singh R, Ibrahim M, Esa N, Iliyana M. 2010. Composting of waste from palm oil mill: a sustainable waste management practice. Rev Environ Sci Biotechnol. Available from http://dx.doi.org/10.1007/ s11157-010-9199-2 (verified 15 March 2010).

Singh RP, Embrandiri A, Ibrahim MH, Esa N. 2011. Management of biomass residues generated from palm oil mill: Vermicomposting a sustainable option. Resour Conserv Recycl 55(4): 423434.

Singleton GR, Belmain S, Brown PR, Aplin K, Htwe NM. 2010. Impacts of rodent outbreaks on food security in Asia. Wildl Res 37 (5): 355-359.

Situmorang E, Nugroho Y, Wicaksono W, et al. 2014. Impact of empty fruit bunches application on soil bacterial biodiversity in oil palm plantation, ICOPE 2014, The Stones Hotel, Bali, Indonesia.

Stenseth NC, Leirs H, Skonhoft A, et al. 2003. Mice, rats, and people: the bio-economics of agricultural rodent pests. Front Ecol Environ 1(7): 367-375.

Stichnothe H, Bessou C. 2017. Challenges for life cycle assessment (LCA) of palm oil production systems under review. Indonesian $J$ Life Cycle Assess Sustain 1(2).

Stichnothe H, Schuchardt F. 2010. Comparison of different treatment options for palm oil production waste on a life cycle basis. Int $J$ Life Cycle Assess 15(9): 907-915.

Stichnothe H, Schuchardt F. 2011. Life cycle assessment of two palm oil production systems. Biomass Bioenerg 35(9): 3976-3984.

Stone WB, Okoniewski JC, Stedelin JR. 2003. Anticoagulant rodenticides and raptors: recent findings from New York, 1998-2001. Bull Environ Contam Tox 70(1): 0034-0040.

Swift MJ, Heal OW, Anderson JM. 1979. Decomposition in terrestrial ecosystems. Univ of California Press.

Taniwiryono D, Herman S. 2016. Policy and financial analysis for development of biogas power plant in palm oil mills. "Technical Cooperation Project of Capacity Development for Low Carbon Development in the Republic of Indonesia" in cooperation between the Japan International Cooperation Agency (JICA) and the Coordinating Ministry for Economic Affairs, the Republic of Indonesia, First edition, Jakarta. 
Tao H-H., Slade EM, Willis KJ, Caliman J-P., Snaddon JL. 2016. Effects of soil management practices on soil fauna feeding activity in an Indonesian oil palm plantation. Agric Ecosyst Environ 218: 133-140.

Taylor IR. 1994. Barn Owls: Predator-prey relationships and conservation. Cambridge: Cambridge University Press.

Teuscher M, Vorlaufer M, Wollni M, Brose U, Mulyani Y, Clough Y. 2015. Trade-offs between bird diversity and abundance, yields and revenue in smallholder oil palm plantations in Sumatra, Indonesia. Biol Conserv 186: 306-318.

Teuscher M, Gérard A, Brose U, et al. 2016. Experimental biodiversity enrichment in oil-palm-dominated landscapes in Indonesia. Front Plant Sci 7(1538).

Tohiruddin L, Foster HL. 2013. Superior effect of compost derived from palm oil mill by-products as a replacement for inorganic fertilisers applied to oil palm. J Oil Palm Res 25(1): 123-137.

Tscharntke T, Klein AM, Kruess A, Steffan-Dewenter I, Thies C. 2005. Landscape perspectives on agricultural intensification and biodiversity: ecosystem service management. Ecol Lett 8(8): 857-874.

Turner PD, Gillbanks RA. 2003. Oil palm cultivation and management. Kuala Lumpur: The Incorporated Society of Planters.

United Plantations Berhad. 2006. Annual Report 2005. United Plantations Berhad, Teluk Intan, Malaysia.

Vakili M, Rafatullah M, Ibrahim MH, Salamatinia B, Gholami Z, Zwain HM. 2015. A review on composting of oil palm biomass. Environ Dev Sustain 17(4): 691-709.

Verwilghen A. 2015. Rodent pest management and predator communities in oil palm plantations in Indonesia: a comparison of two contrasting systems. Thèse de doctorat - sciences de la vie et de la santé. Besançon, université de Franche-Comté, France, $276 \mathrm{p}$.

Verwilghen A, Raoul F, Naim M, et al. 2016a. Small carnivores contribute to rat control in oil palm plantations. In: Sustainable palm oil and climate change: The way forward through mitigation and adaptation. Bali: ICOPE, 1 poster. International Conference on Oil Palm and Environment (ICOPE 2016), 16-18 March 2016, Bali, Indonésie.

Verwilghen A, Jennings AP, Veron G, et al. 2016b. Spatial distribution of small carnivores within oil palm plantations. In: Sustainable palm oil and climate change: The way forward through mitigation and adaptation. Bali: ICOPE, 1 poster. International Conference on Oil Palm and Environment (ICOPE 2016). 16-18 March 2016, Bali, Indonésie.

Vijaya S, Ma AN, Choo YM. 2009. A Gate to Gate Assessment of environmental performance for production of crude palm kernel oil using life cycle assessment approach. Am J Environ Sci 5(3): 267-272.
Wagg C, Bender SF, Widmer F, van der Heijden MGA. 2014. Soil biodiversity and soil community composition determine ecosystem multifunctionality. Proc Nat Acad Sci US A. 111: 5266-5270.

Wahyu A, Philippe R, Pane L, Caliman JP. 2001. Pest damages on the root system of oil palms planted on peat soil. Proceedings of the 2001 PIPOC International Palm Oil Congress (Agriculture) A34: 369-381.

Wezel A, Bellon S, Doré T, Francis C, Vallod D, David C. 2009. Agroecology as a science, a movement and a practice. A review. Agron Sustain Dev 29(4): 503-515.

Wicke B, Dornburg V, Junginger M, Faaij A. 2008. Different palm oil production systems for energy purposes and their greenhouse gas implications. Biomass Bioenerg 32: 1322-1337.

Wilcove D, Koh L. 2010. Addressing the threats to biodiversity from oil-palm agriculture. Biodivers Conserv 19(4): 999-1007.

Wiloso EI, Bessou C, Heijungs R. 2015. Methodological issues in comparative life cycle assessment: treatment options for empty fruit bunches in a palm oil system. Int J Life Cycle Assess 20(2): 204-216.

Wood BJ. 1976. Vertebrate pests. In: Corley RHV, Handan J, Wood BJ, eds. Oil Palm Research. Amsterdam: Elsevier pp. 395-418.

Wood BJ, Chung GF. 2003. A critical review of the development of rat control in Malaysian agriculture since the 1960s. Crop Prot 22(3): 445-461.

Wood BJ, Liau SS. 1984. A long-term study of Rattus tiomanicus populations in an oil palm plantation in Johore, Malaysia: III. Bionomics and natural regulation. J Appl Ecol 21(2): 473-495.

Yahya A, Sye CP, Ishola TA, Suryanto H. 2010. Effect of adding palm oil mill decanter cake slurry with regular turning operation on the composting process and quality of compost from oil palm empty fruit bunches. Bioresource Technol 101: 8736-8741.

Yoshizaki T, Shirai Y, Hassan MA, et al. 2013. Improved economic viability of integrated biogas energy and compost production for sustainable palm oil mill management. J Clean Prod 44(44): 1-7.

Yusoff S. 2006. Renewable energy from palm oil - innovation on effective utilization of waste. J Clean Prod 14(1): 87-93.

Yusoff S, Hansen S. 2005. Feasibility study of performing a life cycle assessment on crude palm oil production in Malaysia (9 pp). Int $J$ Life Cycle Assess 12(1): 50-58.

Zaharah AR, Lim KC. 2000. Oil palm empty fruit bunch as a source of nutrients and soil ameliorant in oil palm plantations. Malaysian $J$ Soil Sci 4: 51-66.

Zhang W, Ricketts TH, Kremen C, Carney K, Swinton SM. 2007. Ecosystem services and dis-services to agriculture. Ecol Econ 64(2): 253-260.

Zulkifli H, Halimah M, Mohd Basri W, Choo YM. 2009. Life cycle assessment for FFB production. In: PIPOC 2009 Palm oil-Balancing Ecologies with Economics. 9-12 November. Kuala Lumpur, Convention Center.

Cite this article as: Bessou C, Verwilghen A, Beaudoin-Ollivier L, Marichal R, Ollivier J, Baron V, Bonneau X, Carron M-P, Snoeck D, Naim M, Ketuk Aryawan AA, Raoul F, Giraudoux P, Surya E, Sihombing E, Caliman J-P. 2017. Agroecological practices in oil palm plantations: examples from the field. OCL 24(3): D305 